
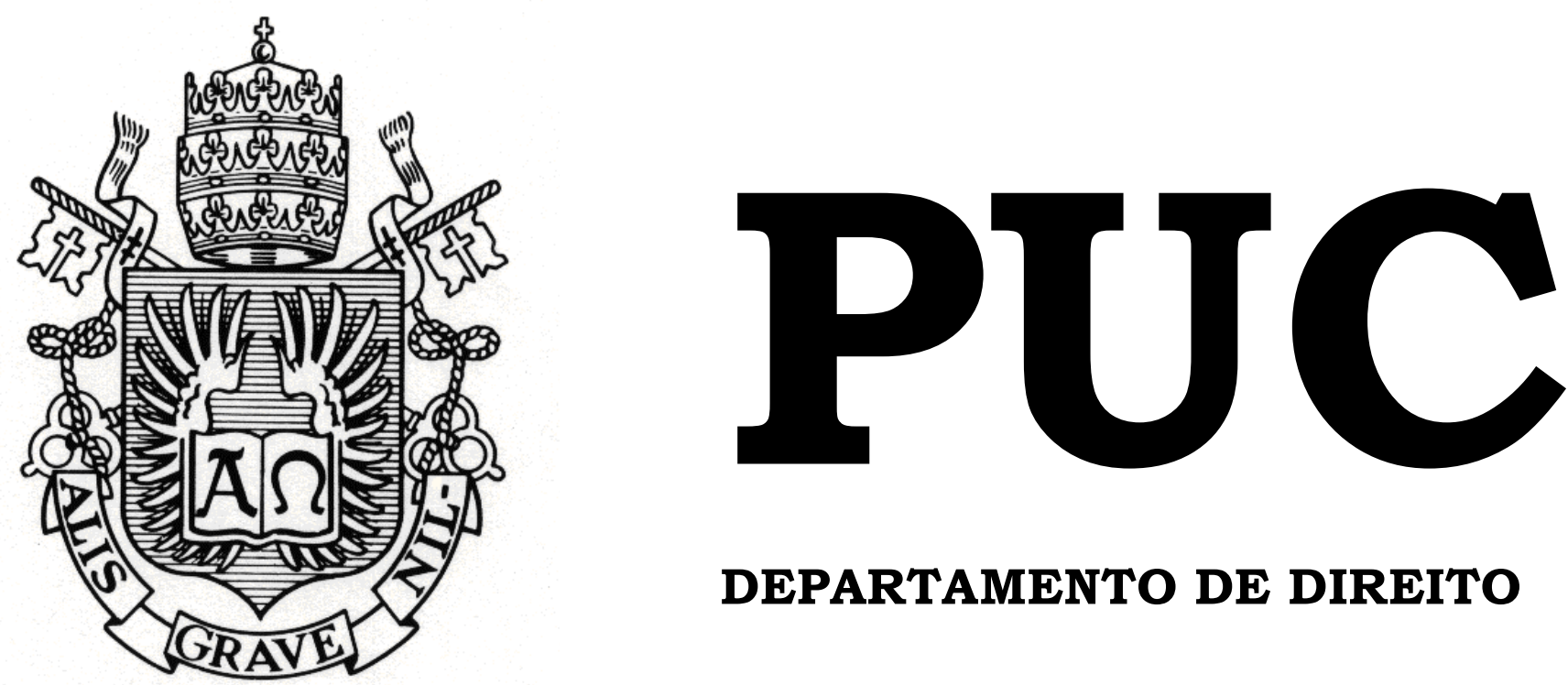

DEPARTAMENTO DE DIREITO

ESTUDO DE CASO GVT - VIVENDI:

UMA ANÁLISE SOBRE OPÇÃO DE COMPRA E CONTROLE NO ESCOPO DAS OFERTAS PÚBLICAS

por

JÚLIA COSTA CASTELO BRANCO

ORIENTADORA: Norma Jonssen Parente

2012.1

PONTIFÍCIA UNIVERSIDADE CATÓLICA DO RIO DE JANEIRO

RUA MARQUÊS DE SÃO VICENTE, 225 - CEP 22453-900

RIO DE JANEIRO - BRASIL 


\title{
ESTUDO DE CASO GVT - VIVENDI: UMA ANÁLISE SOBRE OPÇÃO DE COMPRA E CONTROLE NO ESCOPO DAS OFERTAS PÚBLICAS
}

\author{
por \\ JÚLIA COSTA CASTELO BRANCO
}

Monografia apresentada ao

Departamento de Direito da Pontificia Universidade Católica do Rio de Janeiro (PUC-Rio) como requisito parcial para a obtenção do Título de Bacharel em Direito.

Orientadora: Norma Jonssen Parente 
Aos meus pais, Mônica e José com muito amor 


\section{AGRADECIMENTOS}

Em primeiro lugar, gostaria de agradecer aos meus pais, José e Mônica, por todo o amor, carinho e incentivo e pela dedicação despendida na minha educação. Ao meu pai, uma das pessoas mais inteligentes que conheço, por ter me introduzido ao mundo jurídico e por ler esse trabalho com tanto afinco e orgulho. À minha mãe, por ter me mostrado o que é ser uma mulher forte e bem-sucedida e, principalmente, por ter largado tudo para ficar comigo nos momentos que mais precisei. Obrigada por tudo.

Agradeço ao Thiago, meu irmão, por ter me ajudado a dar altas risadas nos momentos de estresse e por ter me ensinado o que é dedicação e perseverança. Ao Daniel, por ter sido meu melhor amigo e companheiro durante todos esses anos e por ter sido sempre muito paciente com os meus pequenos surtos. Amo vocês.

Agradeço também à Professora Norma Parente, pela sua orientação neste trabalho e por seus valiosos comentários. Muito obrigada por ter lido esta monografia com tanta atenção e por ter me ajudado a construí-la.

Por fim, gostaria de agradecer à Fernanda Bastos e ao Manuel Hermeto, por terem me ensinado tudo que eu sei sobre direito societário. Estendo este agradecimento a todos os meus amigos e colegas de trabalho do escritório Souza, Cescon, Barrieu \& Flesch Advogados, que tornam o meu dia a dia mais interessante e feliz há três anos. 


\section{RESUMO}

O presente trabalho tem como objetivo estudar e analisar, doutrinária e jurisprudencialmente, todos os aspectos societários envolvidos na disputa pública para a aquisição do controle da GVT, que teve como conseqüência a aquisição pela Vivendi do controle acionário da GVT e um posterior procedimento administrativo na CVM contra a Vivendi visando investigar se a mencionada aquisição foi realizada de forma regular. Entre os pontos que serão analisados neste estudo, destacam-se o conceito de controle acionário, os principais aspectos sobre a oferta pública por alienação do controle (OPA obrigatória) e a oferta pública para aquisição do controle (OPA voluntária), com uma comparação dos institutos brasileiros no direito comparado, as chamadas poison pills, a opção de compra para fins de controle e os leading cases da CVM sobre as ofertas públicas por alienação de controle.

Palavras-Chave: controle, oferta pública, GVT, poison pills, opção de compra. 


\section{ABStRAct}

This paper aims to study and analyze, under the scholars and leading cases points of view, all the corporate aspects involved in the public dispute for the acquisition of the control of GVT, which has as its consequence the acquisition by Vivendi of the corporate control of GVT and a administrative procedure filed before CVM against Vivendi in order to inquire if such acquisition was regularly conducted. Among the points that will be herein analyzed, we highlight the definition of corporate control, the main points concerning the mandatory tender offers and the takeovers, with a comparison between the Brazilian institutes and the foreign legislation, the so-called poison pills, the call option for control purposes and the leading cases of CVM regarding the mandatory tender offers.

Key-Words: control, tender offers, takeover, GVT, poison pills, call option. 


\section{SUMÁRIO}

I. INTRODUÇÃO 9

II. A AQUisição do CONTROLE da GVT PELA VIVENDI 12

II.1. O Acordo entre Vivendi e os Controladores da GVT ..........14

II.2. A Oferta Voluntária Lançada pela Telefônica ....................... 18

II.3. A Aprovação da ANATEL ....................................................... 19

II.4. A Aprovação do CADE................................................................. 20

II.5. O Termo de Compromisso firmado com a CVM .................. 21

III. Oferta Pública de AQuisição de AÇões - OPA 26

III.1. A Oferta Pública de Aquisição Obrigatória ........................29

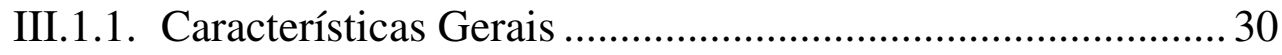

III.1.2. Conceito de Alienação de Controle ....................................... 34

III.1.3. O Prêmio dos Minoritários ...................................................... 42

III.1.4. Análise das Regras de OPA no Direito Comparado.............. 43

III.2. A Oferta Pública Hostil........................................................47

III.2.1. Características Gerais ......................................................... 47

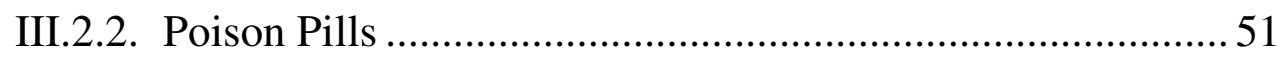

III.2.3. Análise da Oferta Hostil no Direito Comparado ....................56 56

III.3. A Oferta Pública Concorrente ..................................................58

IV. CONTROLE SOCIETÁRIO 61

IV.1. Características Gerais.............................................................61

IV.2. Conceito de Controle para as Agências Reguladoras......... 68

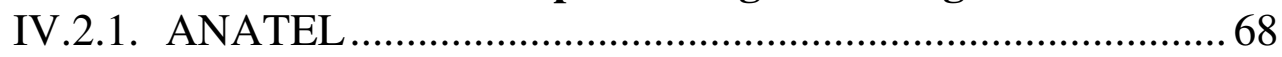

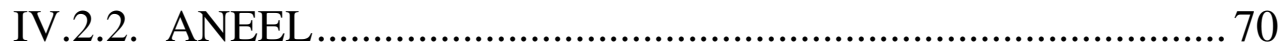

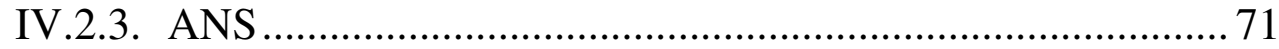

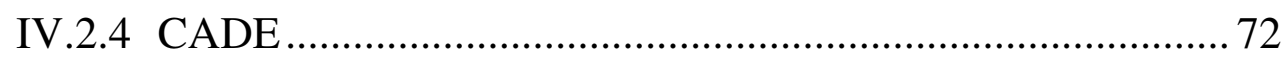

V. ANÁliSE JURISPRUDENCIAL SOBRE ALIENAÇÃo DE CONTROLE 75

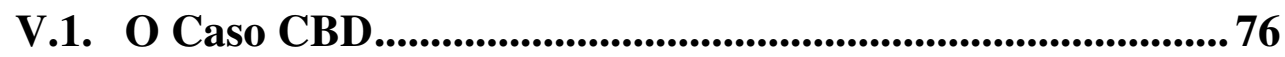

V.2. O Caso Arcelor-Mittal......................................................8 80

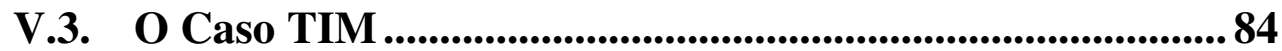

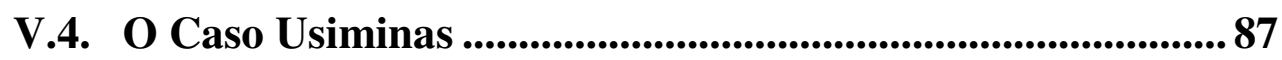

V.5. Outros Casos.........................................................................89 
VI. As OPÇÕES DE COMPRa PaRa CARACTERIZAÇÃO dO CONTROLE

VII. CONCLUSÕES 


\section{DEFINIÇÕES}

ANATEL

ANEEL

ANS

BM\&F Bovespa

CADE

CVM

Lei das Sociedades por

Ações

Lei de Defesa da

Concorrência

Lei do Mercado de

Capitais

SEP

SRE
Agência Nacional de Telecomunicações

Agência Nacional de Energia Elétrica

Agência Nacional de Saúde Suplementar

BM\&F Bovespa S.A. - Bolsa de Valores,

Mercadorias e Futuros

Conselho Administrativo de Defesa

Econômica

Comissão de Valores Mobiliários

Lei ${ }^{\circ}$ 6.404, de 15 de dezembro de 1976

Lei $\mathrm{n}^{\mathrm{o}} 12.529$, de 30 de novembro de 2011

Lei $\mathrm{n}^{\circ}$ 6.385, de 7 de dezembro de 1976

Superintendência de Relações com Empresas da CVM

Superintendência de Registro de Valores

Mobiliários da CVM 


\section{INTRODUÇÃO}

O presente trabalho tem como objetivo estudar temas diversos do direito societário envolvidos no processo de aquisição do controle da GVT pela Vivendi ocorrido no segundo semestre de 2009. Tratase, portanto, de uma análise doutrinária e jurisprudencial de assuntos atuais e controvertidos contidos da Lei das Sociedades por Ações à luz do estudo do caso aqui chamado de GVT - Vivendi.

É importante, no entanto, esclarecer que esta monografia de final de curso não visa estudar de forma detalhada e esgotar todos os assuntos e pontos dos temas aqui abordados, mas trazer os principais conceitos envolvidos no caso GVT - Vivendi, aplicando a teoria do direito societário em um caso prático.

De forma a situar o leitor deste estudo, o primeiro capítulo seguido desta Introdução trata dos fatos envolvidos no processo de aquisição aqui estudado, de acordo e seguindo os fatos relevantes divulgados pelas companhias envolvidas, principalmente pela GVT. Tal capítulo apresenta ainda ao leitor o termo de compromisso firmado pela Vivendi e a CVM no âmbito do Processo Administrativo Sancionador aberto pela autarquia brasileira contra a companhia francesa em razão da divulgação de informações e da condução do negócio de aquisição do controle da GVT.

Já o Capítulo III traz uma análise doutrinária sobre as duas principais modalidades de oferta pública existentes no direito brasileiro: a oferta pública obrigatória por alienação de controle e a oferta voluntária ou oferta hostil. Serão estudados os principais aspectos de tais OPAs e seus pontos controvertidos, além de mostrar 
ao leitor as diferenças entre as duas, principalmente com relação à aplicabilidade.

A oferta pública obrigatória é estudada neste trabalho por ter sido a modalidade lançada pela Vivendi em razão da aquisição do controle da GVT, conforme estabelecido o artigo 254-A da Lei das Sociedades por Ações. Analisamos também os aspectos da oferta hostil, modalidade que seria lançada pela Vivendi a princípio e que foi de fato lançada pela Telefônica para a aquisição do controle da GVT, cujo capital era pulverizado na época. Estudaremos ainda a OPA concorrente, que poderia ter sido lançada pela Vivendi de forma a concorrer com a oferta lançada pela Telefônica.

O quarto capítulo da presente monografia visa tecer comentários ao conceito de controle societário no direito brasileiro, por meio de uma análise doutrinária do artigo 116 da Lei das Sociedades por Ações. O foco neste capítulo é o conceito de controle aplicável nos casos de alienação de controle para fins de oferta obrigatória.

Dentro do Capítulo IV, vamos trazer ainda os conceitos de controle previstos nas diversas normas de agências reguladoras que servem como parâmetro para o pedido de consentimento prévio em razão de alteração de controle perante tais agências.

O Capítulo $\mathrm{V}$ tem como foco uma análise jurisprudencial de casos em que a alienação do controle de determinada companhia foi discutida e, consequentemente, discutiu-se a obrigatoriedade ou não da realização de uma oferta pública. Em outras palavras, trata-se de um capítulo destinado ao estudo dos leading cases da CVM sobre OPA obrigatória. 
Por fim, o Capítulo VI discorre sobre as opções de compra para fins de caracterização de controle, tal como foi feito e muito discutido no caso GVT - Vivendi. Pretendemos responder ao final deste capítulo se o adquirente de opções de compra que lhe garantirão o poder de controle de uma companhia já pode ser considerado como controlador de dita companhia.

Fechamos este trabalho com um sumário de todas as nossas conclusões sobre as discussões e os pontos controvertidos aqui estudados, sem, contudo, entrar no mérito do termo de compromisso celebrado entre a Vivendi e a CVM. 


\section{A AquisiçÃo do CONTROLE dA GVT PELA VIVENDI}

No dia 13 de novembro de 2009, uma sexta-feira 13, a GVT (Holding) S.A. ("GVT") divulgou fato relevante anunciando que o seu controle acionário tinha sido adquirido pela francesa Vivendi S.A. ("Vivendi") por meio de negociações privadas com os antigos controladores da GVT. Tal notícia surpreendeu o mercado brasileiro, o qual esperava que a Vivendi lançasse uma oferta pública concorrente à oferta voluntária lançada pela Telecomunicações de São Paulo S.A. - Telesp, sociedade do grupo Telefônica ("Telefônica"). O presente capítulo tem como objetivo estudar como foi realizada tal aquisição do controle da GVT pela Vivendi.

Em um primeiro momento, faz-se necessário conhecer um pouco das duas sociedades envolvidas na operação ora estudada. A GVT foi criada pelo israelense Amos Genish, que, juntamente com outros dois sócios, fundou a Global Village Telecom em Miami com o objetivo de oferecer telefonia rural por satélite. Tal sociedade operava também na América Latina e na Ásia.

A GVT começou a operar no Brasil quando foi convidada pela Inepar (acionista da OI) a participar de um leilão da Anatel de licenças para nove estados e mais Brasília em 1999. A Inepar desistiu de participar do leilão três dias antes de sua realização, mas a GVT resolveu disputar sozinha e conseguiu vencer o leilão por se comprometer a cobrir mais cidades e oferecer mais linhas telefônicas em dois anos do que a sua única concorrente, a Vesper.

Doze anos depois, a GVT tornou-se referência no mercado de telecomunicações do Brasil e é a empresa que possui maior margem 
de lucro: $42 \%$. Além disso, a companhia dispõe da melhor tecnologia de banda larga e, com os investimentos feitos pela Vivendi, é atualmente a operadora que mais cresce no Brasil: em dois anos, sua receita dobrou e hoje corresponde a $\mathrm{R} \$ 3,4$ bilhões.

A Vivendi, por outro lado, é um grupo francês líder global em comunicação e entretenimento. Ela controla a "Activision Blizzard" (a primeira em vídeo games a nível global), "Universal Music Group" (número 1 em música a nível global), SFR (número 2 da França em telefonia móvel e fixa), "Maroc Telecom group" (número 1 em telefonia fixa do Marrocos), "Canal + Group" (número 1 em TV por assinatura da França) e ainda detém 20\% da NBCU (uma das líderes em mídia e entretenimento nos Estados Unidos).

A aquisição do controle da GVT marcou a entrada do grupo francês no setor de telecomunicações brasileiro. Antes de dita operação, a Vivendi atuava no Brasil somente no mercado de música. Além do Brasil, a Vivendi atua também em aproximadamente 75 países e possui aproximadamente 43.000 empregados.

Feitas essas primeiras considerações sobre as áreas de atuação da GVT e da Vivendi, iremos agora analisar o processo que acarretou na aquisição do controle da GVT, incluindo o acordo entre a Vivendi e os controladores da GVT, a oferta pública voluntária lançada pela Telefônica, a aprovação da ANATEL, a aprovação sem restrições do CADE e o termo de compromisso firmado com a CVM. 


\section{II.1. O Acordo entre Vivendi e os Controladores da GVT}

Em 19 de agosto de 2009, a GVT divulgou fato relevante informando ao mercado que a Global Village Telecom (Holland) B.V., Swarth Investments LLC, Swarth Investments Holding LLC, que fazem parte do seu grupo de controle, e Swarth Management LLC decidiram realizar oferta secundária de ações da GVT no mercado de balcão não organizado brasileiro. Ao final da oferta, os controladores da GVT permaneceriam com 5\% do capital social de tal companhia, não havendo mudança de controle nos termos da Resolução ${ }^{\circ}{ }^{101 / 99}$ da ANATEL.

No dia $1^{\circ}$ de setembro de 2009 , a GVT divulgou novo fato relevante reforçando a oferta secundária de ações a ser lançada pelos acionistas controladores de tal sociedade, os quais pretendiam oferecer um total de 24 milhões de ações na oferta pública. Além disso, tal fato relevante esclareceu que a Swarth Management LLC não entraria no grupo de acionistas vendedores.

No entanto, oito dias após a divulgação do fato relevante acima mencionado, a GVT informou ao mercado que (i) a oferta pública de ações anunciada no dia 19 de agosto de 2009 estava cancelada; e (ii) a Vivendi havia assinado um acordo com o Grupo Swarth e com a Global Village Telecom (Holland) B.V., os acionistas fundadores e controladores da GVT, o qual permitia que a Vivendi lançasse uma oferta pública amigável para a aquisição de 100\% do capital da GVT ao preço de $\mathrm{R} \$ 42,00$ por ação, sujeita a determinadas condições.

As condições para o lançamento da oferta pública amigável da Vivendi, que deveriam ser completadas até 16 de outubro de 2009, 
eram as seguintes: (i) auditoria legal confirmatória; (ii) aprovação societária por parte da Vivendi; (iii) aprovação da ANATEL; e (iv) dispensa da aplicação dos mecanismos de proteção de dispersão da base acionária previstos no estatuto da GVT em favor da oferta da Vivendi (waiver da poison pill).

A oferta da Vivendi estava condicionada ainda à aquisição de, no mínimo, 51\% do capital social da GVT, considerando a alta dispersão acionária de tal companhia. Além disso, os acionistas controladores da GVT comprometeram-se a alienar para a Vivendi um mínimo de $20 \%$ de um total de $30 \%$ das ações que detinham na GVT.

Em 19 de outubro de 2009, a GVT divulgou novo fato relevante informando que a Vivendi tinha concluído de forma satisfatória a auditoria legal e que o conselho de administração da Vivendi tinha autorizado a realização de uma oferta para a aquisição de ações representativas da totalidade do capital social da GVT.

Tanto a oferta que seria lançada pela GVT quanto a oferta lançada pela Telefônica (conforme explicado abaixo) era condicionada ao waiver da poison pill prevista nos artigos 43 e 44 do estatuto social da GVT. Iremos estudar com mais detalhadamente o conceito dos mecanismos de proteção de dispersão da base acionária no Capítulo III abaixo. Neste momento, cabe apenas salientar que no dia 3 de novembro de 2009, os acionistas da GVT aprovaram, em assembleia extraordinária, a dispensa da poison pill prevista.

A poison pill foi dispensada para aquisições de ações da GVT que tiverem as seguintes características: (i) a liquidação financeira deveria ocorrer até dia 28 de fevereiro de 2010; (ii) o preço deveria 
ser de, no mínimo, $\mathrm{R} \$ 48,00$ por ação; (iii) o pagamento deveria ser feito em dinheiro; e (iv) o ofertante deveria (a) possuir capacidade financeira para a aquisição de $100 \%$ do capital social da GVT por um preço mínimo de $\mathrm{R} \$ 48,00$ por ação; (b) ser operador ou provedor de serviços de telefonia fixa, móvel ou de banda larga no Brasil e no exterior, diretamente ou por intermédio de suas subsidiárias, controladas ou coligadas.

Conforme informado no fato relevante divulgado pela GVT em 13 de novembro de 2009, a Vivendi celebrou nesta mesma data contrato de compra e venda de ações com Swarth Investments L.L.C., Swarth Investments Holdings L.L.C. e Global Village Telecom (Holland) B.V., os acionistas controladores e fundadores da GVT, por meio do qual adquiriu 38.422.666 ações ordinárias emitidas pela GVT, correspondentes a $29,9 \%$ do seu capital total e votante. Tais ações foram adquiridas a um preço de $\mathrm{R} \$ 56,00$ por ação.

A Vivendi ainda adquiriu de terceiros adicionais 10.286.631 ações ordinárias de emissão da GVT, correspondentes a 8\% do capital total e votante desta companhia. Além disso, a Vivendi celebrou com terceiros opções de compra não condicionadas, adquirindo o direito de compra de outras 25.134.327 ações ordinárias da GVT, correspondentes a $19,6 \%$ do seu capital total e votante.

Com todas as operações descritas acima, a Vivendi adquiriu $37,9 \%$ do capital total e votante da GVT e, adicionalmente, possuía o direito de compra de 19,6\% do capital total e votante da GVT. Após exercidas as opções de compra, a Vivendi deteria 57,5\% do capital total e votante da GVT e 53,7\% do "fully diluted capital", ou seja, se forem consideradas como emitidas todas as ações resultantes de títulos e opções conversíveis em ações da GVT. 
De forma a cumprir com o disposto na legislação societária brasileira, a Vivendi anunciou ainda naquela data que iria apresentar uma oferta pública obrigatória por alienação de controle a um preço de $\mathrm{R} \$ 56,00$ por ação para aquisição de até $100 \%$ das ações de emissão da GVT. Com a oferta da Vivendi, a GVT foi avaliada em $\mathrm{R} \$ 7,2$ bilhões.

Após a implementação da operação descrita acima, a GVT divulgou diversos fatos relevantes informando o aumento da participação da Vivendi no seu capital social pela aquisição de ações adicionais, além do exercício das opções de compra que detinha, consolidando a sua posição de acionista controladora da GVT.

Em 5 de janeiro de 2010, a participação detida pela Vivendi no capital social da GVT passou para 85,7\%, comparada a uma participação de 78,7\% em 10 de dezembro de 2009 e de 57,5\% em 13 de novembro de 2009. Além disso, de acordo com o fato relevante divulgado pela GVT nesta última data, a Vivendi exerceu todas as opções de compra adquiridas em 13 de novembro de 2009 antes de 23 de dezembro de 2009. Em 8 de janeiro de 2010, a Vivendi anunciou os termos da oferta pública por alienação do controle, que também teria como objetivo o cancelamento do registro de companhia aberta da GVT perante a CVM.

Finalmente, no dia 27 de abril de 2010 a Vivendi e a GVT anunciaram na França e no Brasil, respectivamente, o fim do leilão da oferta pública de aquisição de ações por alienação do controle lançada pela Vivendi com relação às ações de emissão da GVT. Como resultado deste leilão, a Vivendi passou a deter $99,17 \%$ do 
capital social da GVT. O registro de companhia aberta da GVT perante a CVM foi cancelado em 7 de maio de 2010.

\section{II.2. A Oferta Voluntária Lançada pela Telefônica}

No dia 7 de outubro de 2009, a Telefônica divulgou fato relevante segundo o qual o seu conselho de administração havia aprovado o lançamento de uma oferta pública voluntária para aquisição de até $100 \%$ das ações emitidas pela GVT ao preço de $\mathrm{R} \$ 48,00$ por ação. Tal oferta estava sujeita às seguintes condições: (i) aquisição de, no mínimo, $51 \%$, e, no máximo, $100 \%$ das ações de emissão da GVT; (ii) dispensa da aplicação dos mecanismos de proteção de dispersão da base acionária previstos no estatuto social da GVT em favor da oferta da Telefônica; e (iii) aprovação da aquisição das ações da GVT pela ANATEL, sem a imposição de restrições e condições senão aquelas adotadas usualmente pela ANATEL em casos precedentes. O leilão da Telefônica estava marcado para o dia 19 de novembro de 2009. A oferta lançada pela Telefônica não caracterizou uma oferta concorrente, conforme vamos estudar no Capítulo III abaixo.

Logo após a assembleia geral extraordinária que resolveu pela dispensa dos mecanismos de proteção da dispersão da base acionária da GVT, a Telefônica lançou novo fato relevante informando um incremento no preço da oferta pública voluntária de $\mathrm{R} \$ 48,00$ por ação

para $\mathrm{R} \$ 50,50$ por ação. Conforme o artigo $261, \S 1^{\circ}$ da Lei das Sociedades por Ações, o ofertante pode aumentar o preço apenas uma única vez e até 10 dias antes do término do prazo da oferta. 
O incremento do preço da oferta pública da Telefônica não parece ter sido feito em momento apropriado. Apesar de a Vivendi não ter se pronunciado mais a respeito da aquisição da GVT, era notório o seu interesse e o mercado aguardava pela sua oferta pública, concorrente à oferta da Telefônica. Nesse sentido, a Telefônica poderia ter esperado uma eventual oferta da Vivendi até o prazo máximo de 10 dias antes da sua oferta para fazer o incremento de preço.

Tendo em vista que o controle da GVT fora adquirido pela Vivendi, conforme explicado no item acima, o leilão da Telefônica, marcado para o dia 19 de novembro de 2009, não atingiu o percentual mínimo de 51\% das ações emitidas pela GVT, não cumprindo então uma das condições previstas no edital da oferta.

\section{II.3. A Aprovação da ANATEL}

Como iremos aprofundar no Capítulo IV abaixo, a ANATEL deve aprovar previamente a alteração do controle de qualquer empresa regulada por tal agência, como no caso da GVT. Assim, era imprescindível a aprovação da ANATEL como órgão regulador para a transferência do controle da GVT pretendido tanto pela Telefônica como pela Vivendi. Vale ressaltar que tanto a Telefônica como a Vivendi incluíram tal aprovação prévia como condição para a oferta lançada ou pretendida por tais companhias.

A ANATEL autorizou de forma prévia, em 12 de novembro de 2009, a transferência do controle da GVT tanto para a Vivendi como para a Telefônica. Tal agência reguladora não estabeleceu qualquer condição para a aquisição do controle da GVT pela Vivendi por se 
tratar de uma empresa que não opera no mercado brasileiro. Vale salientar que houve um voto vencido nesta decisão.

Já com relação à Telefônica, a ANATEL estabeleceu algumas condições para a aquisição do controle da GVT, tais como: (i) exigência de manter estruturas administrativas, operacionais, funcionais e comerciais autônomas e independentes; e (ii) manter o nível de emprego, operando de forma separada, contábil e financeiramente, preservada a marca GVT, pelo prazo de cinco anos a contar da data da concretização da operação.

No dia 27 de janeiro de 2011, a ANATEL aprovou o ato de concentração da aquisição do controle da GVT pela Vivendi sem fazer qualquer restrição, já que a Vivendi não atuava no mercado brasileiro até a compra da GVT.

\section{II.4. A Aprovação do CADE}

Tendo em vista que o faturamento da GVT anual é superior a R\$400 milhões, é necessária a análise do CADE do ato de concentração decorrente da aquisição do controle de dita companhia pela Vivendi. O órgão antitruste brasileiro analisou tal ato de concentração e, no dia 23 de março de 2011, aprovou a aquisição do controle da GVT pela Vivendi sem qualquer restrição, por não existir risco concorrencial no negócio. 


\section{II.5. O Termo de Compromisso firmado com a CVM}

No âmbito do Processo Administrativo Sancionador CVM RJ 2010/2419, que teve como objetivo analisar as operações, os procedimentos e a divulgação das informações relativas à aquisição do controle da GVT, a Vivendi celebrou Termo de Compromisso com a CVM comprometendo-se a pagar $\mathrm{R} \$ 150$ milhões a tal autarquia.

Em tal processo administrativo sancionador, a Vivendi foi acusada de:

(i) induzir ou manter terceiros em erro com finalidade de obter vantagem indevida, prática qualificada como operação fraudulenta, em virtude de ter divulgado fato relevante de modo incompleto em 13 de novembro de 2009, levando o mercado a crer que, naquela data, a Vivendi já era titular de ações e direitos sobre ações da GVT em quantidade suficiente para impedir que o controle acionário da companhia fosse adquirido por terceiro (infração ao disposto no item 1 da Instrução CVM 08/79, no tipo específico do inciso II, alínea “c”);

(ii) não detalhar as condições da aquisição do controle da GVT que eram relevantes, já que um dos contratos de opções de compra, relativo a $9,7 \%$ do capital social da companhia adquirida, fora celebrado com terceiro que ainda não detinha a titularidade das ações, prevendo liquidação exclusivamente financeira, de modo que haveria necessidade de comprar as ações no mercado para assegurar a aquisição do controle acionário da 
GVT (infração ao disposto no $\operatorname{artigo~} 3^{\circ}, \S 5^{\circ}$ e no artigo 10 da Instrução CVM 358/02);

(iii) negociar com ações e títulos referenciados em ações posteriormente à divulgação do fato relevante de 13 de novembro de 2009, de posse de informação relevante não divulgada sobre os direitos que lastreavam parte das opções contratadas pela Vivendi (infração ao disposto no $\$ 4^{\circ}$ do artigo 155 da Lei das Sociedades por Ações e no artigo $13, \S^{\circ}$ da Instrução CVM 358/02); e

(iv) publicar fatos relevantes nos dias $1^{\circ}, 4$ e 11 de dezembro de 2010 com informações imprecisas e incompletas referentes à participação no capital social da GVT pela Vivendi (infração ao disposto no artigo $3^{\circ}$, $\$ 5^{\circ}$ da Instrução CVM 358/02).

Tais acusações foram feitas depois da análise da Área Técnica das operações envolvidas na compra do controle da GVT. Em tal análise, foi concluído pela Área Técnica da CVM que, apesar de a Vivendi ter contratado o direito de adquirir ações de emissão da GVT junto à T.C. LLP, representativas de 19,4\% do capital social da companhia adquirida, esta contraparte não possuía direitos a serem liquidados fisicamente sobre, pelo menos, 8,7\% das ações emitidas pela GVT, direitos estes que eram lastreados em "Certificados Nomura".

Os Certificados Nomura foram emitidos pelo Nomura Bank International e cada título (i) representava o direito financeiro equivalente a uma ação da GVT; (ii) possuía prazo de vencimento de um ano, sem direito de resgate antecipado; (iii) apresentava "delta um” em relação à variação da cotação das ações da GVT; e (iv) era 
sujeito à liquidação exclusivamente financeira e, portanto, não conferia o direito de adquirir ações emitidas pela GVT.

De acordo com o termo de acusação, a Vivendi sabia no momento da divulgação do fato relevante de 13 de novembro de 2009 que os Certificados Nomura não conferiam direito de liquidação física. Desta forma, quando divulgou a aquisição do controle da GVT, a Vivendi possuía no máximo 47,8\% de uma participação efetiva em ações ou em direitos de aquisição de ações. A SEP entendeu que a condição dos Certificados Nomura, os quais eram lastreados apenas por direitos financeiros sobre ações, era relevante e deveria ter sido detalhada no fato relevante divulgado pela GVT.

Ademais, a SEP ainda entendeu que, embora o contrato envolvendo direitos sobre $9,7 \%$ das ações emitidas pela GVT objetivasse o acesso a tais ações, o fato de que a T.C. LLP teria que adquirir no mercado tal percentual de ações da GVT para honrar o contrato firmado com a Vivendi levava à conclusão, segundo a SEP, que o controle da GVT poderia ainda ser adquirido por terceiros. A SEP ressalta que o controle da GVT estava na época sendo alvo de uma oferta pública voluntária de aquisição.

Além disso, segundo o termo de acusação, a Vivendi teria divulgado de forma incompleta as informações sobre as operações adicionais realizadas por ela no mercado visando consolidar a sua posição de acionista controladora. No caso concreto, a Vivendi atuou no mercado adquirindo ações ou direitos sobre ações da GVT ciente das características dos ativos que lastreavam os Certificados Nomura, cuja divulgação não havia sido feita de forma completa e detalhada.

A SEP também concluiu que houve irregularidades na divulgação dos fatos relevantes da GVT de $1^{\circ}, 4$ e 11 de dezembro de 
2009, já que tais fatos relevantes informaram a participação da Vivendi no capital social da GVT sem considerar as opções de compra que ainda não haviam sido exercidas. Desta forma, o montante informado pela Vivendi estaria diferente da posição acionária constante dos registros de acionistas da GVT.

Em sua primeira proposta de termo de compromisso, a Vivendi apresentou defesa refutando os argumentos levantados pela SEP do termo de acusação. Segundo tal companhia, a oferta pública voluntária de aquisição de ações lançada pela Telefônica foi frustrada não pela não divulgação de informação supostamente relevante, mas sim porque o preço pago em tal oferta era inferior e não alcançaria o preço pago pela Vivendi pelas ações adquiridas e que seria pago aos aderentes da oferta pública obrigatória por alienação de controle. Tal informação teria sido, inclusive, reconhecida pelos representantes da Telefônica de forma pública e voluntária.

A Vivendi argumenta ainda que a oferta lançada pela Telefônica era inviável por não haver chances reais e concretas de tal companhia adquirir no mínimo 51\% do capital social da GVT.

Em tal proposta e adicionalmente aos argumentos de defesa apresentados, a Vivendi comprometeu-se a pagar o montante de $\mathrm{R} \$ 5$ milhões para a CVM. No entanto, o Comitê de Termo de Compromisso entendeu que a proposta apresentada pela Vivendi não atendia aos requisitos mínimos estabelecidos em lei e, portanto, a celebração do termo de compromisso era inadequada, inconveniente e inoportuna.

Diante da manifestação do Comitê de Termo de Compromisso contrária à proposta apresentada pela Vivendi, tal companhia 
resolveu apresentar um aditamento à sua proposta, segundo o qual a Vivendi se comprometeria a pagar para a CVM o montante de R $\$ 150$ milhões. O colegiado da CVM deliberou e resolveu pela aceitação da proposta aditada apresentada pela Vivendi por entendê-la oportuna e conveniente, já que o valor do termo compromisso seria proporcional à gravidade das imputações formuladas contra a companhia e, portanto, seria suficiente para desestimular a prática de condutas semelhantes.

Após a análise de todo o processo que resultou na aquisição do controle societário pela Vivendi, incluindo as consequências de tais operações perante a CVM, cumpre-nos agora passar para o estudo dos institutos envolvidos em tal processo, quais sejam, a oferta pública obrigatória por alienação do controle, tal como a lançada pela Vivendi, a oferta pública voluntária (ou oferta hostil) lançada pela Telefônica, a oferta concorrente, a qual o mercado esperava que a Vivendi lançasse, as poison pills, o conceito de controle societário e os efeitos práticos das opções de compra de ações. 


\section{Oferta Pública de Aquisição de Ações - OPA}

A Lei das Sociedades por Ações trouxe para o direito societário brasileiro duas modalidades de oferta pública de aquisição de ações ou, simplesmente, OPA, relacionadas à transferência do controle acionário de uma companhia aberta. A primeira é a OPA obrigatória por alienação de controle, prevista no artigo 254-A da Lei das Sociedades por Ações e neste trabalho chamada simplesmente de OPA obrigatória. A outra modalidade é a OPA para aquisição do controle, aqui tratada como OPA voluntária, prevista no artigo 257 e seguintes da lei societária e também conhecida como oferta hostil, conforme veremos adiante.

A primeira diferença entre tais modalidades de oferta pública diz respeito ao momento de sua realização. Enquanto a OPA obrigatória é realizada a posteriori, ou seja, após a alienação privada do controle, a OPA voluntária é a priori, sendo uma forma de tomada do controle de determinada companhia com alto grau de dispersão acionária.

No caso ora estudado, vimos que o capital da GVT, antes da aquisição pela Vivendi, era pulverizado no mercado, sendo aproximadamente $30 \%$ das ações de tal companhia detidas pelos seus fundadores e as demais dispersas no mercado. Sendo assim, a aquisição do controle de tal companhia por meio da realização de uma oferta pública voluntária deveria ser considerada.

De fato, a Vivendi pretendia, em um primeiro momento, realizar uma oferta voluntária para a aquisição do controle da GVT. Vale ressaltar que esta foi a OPA lançada pela Telefônica na sua tentativa de adquirir o controle de tal companhia. Contudo, a Vivendi 
decidiu negociar de forma privada a aquisição de ações que lhe garantiram o controle da GVT, ficando obrigada, no entanto, a realizar a OPA por alienação de controle.

Não restam dúvidas, portanto, com relação à aplicabilidade da OPA voluntária ou da OPA obrigatória: a primeira é realizada antes da aquisição do controle e a segunda é realizada após este momento. Além disso, tais modalidades de oferta pública se diferem no seu objetivo final, que pode ser a aquisição do controle, no caso da OPA voluntária, ou assegurar aos minoritários tratamento igual ao do controlador, no caso da OPA obrigatória. Sobre este assunto, leciona José Alexandre Tavares Guerreiro:

"Não se tem em mira, aqui [no artigo 254-A], a aquisição do controle, mas a proteção patrimonial dos acionistas minoritários, que não sejam parte do negócio translativo do controle e que devem ter a oportunidade de transferir suas ações pelo mesmo preço e nas mesmas condições aplicáveis ao alienante do controle."1

A Superintendência Jurídica da CVM se manifestou nesse mesmo sentido, acrescentando que, enquanto a filosofia da OPA obrigatória é "o reconhecimento do princípio de que o valor do controle pertence a todos os acionistas", , a filosofia da OPA voluntária é a "garantia do investidor contra ofertas inidôneas e quanto ao acesso às informações necessárias à sua tomada de decisão"3.

Outro aspecto importante no que diz respeito à aplicabilidade da OPA obrigatória e da OPA hostil está relacionado à composição

\footnotetext{
${ }^{1}$ GUERREIRO, José Alexandre Tavares. Alienação de controle de companhia aberta: o papel das instituições financeiras. Revista de Direito Mercantil, Industrial, Econômico e Financeiro. São Paulo: Malheiros, n. 30. p.116. 1978.

${ }^{2}$ Oferta Pública de aquisição de controle: artigo 257 e seguintes da Lei 6.404/76. Estudos da Superintendência Jurídica da CVM, citação p. 32, publicado em agosto de 1979.

${ }^{3}$ Oferta Pública de aquisição de controle: artigo 257 e seguintes da Lei 6.404/76. Estudos da Superintendência Jurídica da CVM, citação p. 33, publicado em agosto de 1979.
} 
do capital da companhia aberta cujo controle está sendo adquirido. A OPA hostil, como mencionamos, só tem sentido em companhias cujo capital encontra-se diluído, ou seja, mais de $51 \%$ de tal capital seja sendo negociado em bolsa. Ora, já que seu objetivo é a aquisição do controle, a OPA hostil feita em uma companhia em que se é impossível adquirir o controle por meio de oferta pública perde totalmente o seu objeto.

Já a OPA obrigatória geralmente é realizada em companhias cujo controle é exercido por um acionista que detém a maioria das ações com direito a voto (chamado controle majoritário ou concentrado). Como no mercado brasileiro prevalecem as companhias com controle concentrado, sem dispersão acionária, a maioria das transferências de controle é feita por contrato particular de compra e venda, incidindo a obrigatoriedade de oferta pública nos termos do artigo 254-A da Lei das Sociedades por Ações.

Por fim, vale mencionar nesta prévia introdução ao estudo das OPAs as modalidades de oferta pública estabelecidas no artigo $2^{\circ}$ da Instrução CVM 361/02: (i) OPA para cancelamento de registro, que é aquela obrigatória, realizada com condição do cancelamento de registro de companhia aberta; (ii) OPA por aumento de participação, que é obrigatória e realizada em consequência do aumento da participação do acionista controlador; (iii) OPA por alienação de controle, que chamamos de OPA, obrigatória neste trabalho, e que é realizada como condição de eficácia de negócio jurídico de alienação de controle de companhia aberta; (iv) OPA voluntária, que tem como objetivo aquisição de ações de emissão de companhia aberta que não representa controle; (v) OPA para aquisição de controle de companhia aberta, que neste trabalho chamamos de OPA voluntária; e (vi) OPA concorrente, que é aquela apresentada por terceiros que 
não o ofertante e que tem como objeto ações abrangidas pela OPA em curso. Note-se que a OPA para cancelamento de registro e a OPA por aumento de participação também estão previstas na Lei das Sociedades por Ações, nos $\S \S 4^{\circ}$ e $6^{\circ}$ do artigo $4^{\circ}$, respectivamente. Vale ainda mencionar que é possível a unificação de OPAs, ou seja, uma oferta pública pode ter dois objetivos distintos dentre os mencionados acima.

Passaremos agora à análise mais detalhada das duas modalidades de OPA previstas na Lei das Sociedades por Ações e que foram realizadas no âmbito da aquisição do controle da GVT pela Vivendi: a OPA obrigatória e a OPA voluntária. Vamos também estudar neste capítulo a OPA concorrente mencionada no subitem (vi) acima.

\section{III.1. A Oferta Pública de Aquisição Obrigatória}

A Vivendi foi obrigada a realizar uma oferta pública de aquisição obrigatória por ter adquirido o controle da GVT, conforme mencionamos acima. A OPA obrigatória está prevista no artigo 254A da Lei das Sociedades por Ações, in verbis:

"Art. 254-A. A alienação, direta ou indireta, do controle de companhia aberta somente poderá ser contratada sob a condição, suspensiva ou resolutiva, de que o adquirente se obrigue a fazer oferta pública de aquisição das ações com direito a voto de propriedade dos demais acionistas da companhia, de modo a lhes assegurar o preço no mínimo igual a $80 \%$ (oitenta por cento) do valor pago por ação com direito a voto, integrante do bloco de controle.

$\S 1 \underline{\text { o }}$ Entende-se como alienação de controle a transferência, de forma direta ou indireta, de ações integrantes do bloco de controle, de ações vinculadas a acordos de acionistas e de valores mobiliários conversíveis em ações com direito a voto, cessão de direitos de subscrição de ações e de outros títulos ou direitos relativos a valores mobiliários conversíveis 
em ações que venham a resultar na alienação de controle acionário da sociedade.

§ 2o A Comissão de Valores Mobiliários autorizará a alienação de controle de que trata o caput, desde que verificado que as condições da oferta pública atendem aos requisitos legais.

$\S 3 \underline{o}$ Compete à Comissão de Valores Mobiliários estabelecer normas a serem observadas na oferta pública de que trata o caput.

$\S 4 \underline{\text { o }} \mathrm{O}$ adquirente do controle acionário de companhia aberta poderá oferecer aos acionistas minoritários a opção de permanecer na companhia, mediante o pagamento de um prêmio equivalente à diferença entre o valor de mercado das ações e o valor pago por ação integrante do bloco de controle."

\section{III.1.1. Características Gerais}

Vale ressaltar que o artigo 254-A, incluído na Lei das Sociedades por Ações pela Lei $n^{\circ} 10.303 / 01$, reintroduziu no direito societário brasileiro o instituto da oferta pública obrigatória da aquisição das ações dos minoritários, com pequenas mudanças da OPA obrigatória originalmente estabelecida pelo legislador de 1976.

O artigo 254 previa originalmente a obrigação do adquirente do controle de uma companhia aberta de pagar aos acionistas minoritários o mesmo preço que havia pago ao alienante de tal controle. Tal dispositivo foi revogado da legislação societária pela Lei $n^{\circ} 9.457 / 97$, eliminando o instituto da oferta pública obrigatória do ordenamento jurídico brasileiro, com o objetivo de beneficiar o governo na privatização de empresas estatais. A revogação desta modalidade da OPA foi considerada um grande retrocesso na época para o direito societário brasileiro.

Em 2001, depois de concluídas as privatizações, o legislador resolveu reintroduzir a OPA obrigatória no caso de alienação de controle de companhia aberta. No entanto, o artigo 254-A não 
restaurou o princípio de tratamento igualitário nos termos do antigo artigo 254, mas determinou que o adquirente do controle deve pagar aos minoritários no mínimo $80 \%$ do preço pago ao alienante do controle $^{4}$. O artigo 254-A "atribui, portanto, ao bloco de controle uma mais-valia, permitindo que as ações que o integram recebam um preço superior ao das ações dos minoritários."

O objetivo do artigo 254-A continuou sendo o de proteger o acionista minoritário, conferindo-lhe o direito de participar no ágio ou prêmio pago pelo adquirente do controle, mesmo que não tenha sido conferido a ele tratamento igualitário ao alienante do controle. Por tal motivo, o artigo 254-A é conhecido como o direito de tag along dos acionistas minoritários de uma companhia aberta. Assim, devemos ter em mente que o instituto da OPA obrigatória foi reintroduzido para garantir que o acionista minoritário possa vender suas ações por um preço quase similar ao preço pago ao acionista controlador, se desejar sair da companhia, ou ainda receber um prêmio caso resolva continuar investindo naquela companhia, como veremos mais adiante.

Conforme o exposto, o direito previsto no artigo 254-A é garantido exclusivamente aos acionistas minoritários de uma companhia aberta, ou seja, aquela companhia cujos valores mobiliários estejam admitidos à negociação no mercado de valores mobiliários. No entanto, os acordos de acionistas celebrados para regular os direitos de voto e a compra e venda de ações em

\footnotetext{
${ }^{4}$ No entanto, há previsão no Brasil de tag along de 100\%. O Regulamento de Listagem do Novo Mercado estabelece em seu item 8.1 que em caso de alienação de controle de uma companhia listada no Novo Mercado da BM\&F Bovespa, deverá ser realizada oferta pública de modo a assegurar tratamento igualitário aos acionistas minoritários. Da mesma forma estabelece o Regulamento de Listagem do Nível 2 para as companhias listadas em tai nível a partir de 10 de maio de 2011.

5 CARVAlHOSA, Modesto. Comentários à Lei das Sociedades Anônimas. $4^{\circ}$ volume. Tomo II. $4^{\text {a }}$ edição. São Paulo: Saraiva, 2011. p. 197.
} 
companhias fechadas geralmente preveem um direito similar ao direito legal previsto no mencionado artigo.

No âmbito das companhias fechadas, tal direito também é chamado de tag along e confere ao acionista minoritário signatário do acordo a possibilidade de alienar as suas ações nos termos e condições pactuados em vista da venda das ações do acionista controlador. No entanto, é importante esclarecer que este direito deve ser previsto contratualmente, enquanto o tag along conferido a todos os acionistas minoritários de companhia aberta decorre da lei, não sendo derrogável pela vontade das partes.

Outro ponto do caput do artigo 254-A que merece destaque diz respeito aos acionistas minoritários para os quais é dirigida a oferta pública: apenas aqueles que possuem ações com direito a voto e que não integram o bloco de controle. Como sabemos, isso não importa em dizer que apenas os acionistas minoritários detentores de ações ordinárias são os destinatários de tal oferta, mas também (i) os preferencialistas aos quais o estatuto social da companhia não negou o direito a voto; (ii) os preferencialistas com voto restrito; (iii) os preferencialistas que adquirirem o direito a voto, conforme artigo $111, \S 1^{\circ}$ da Lei das Sociedades por Ações; e (iv) os preferencialistas aos quais não foi atribuído nem o direito ao dividendo prioritário nem ao dividendo $10 \%$ maior do que o das ações ordinárias. Importante esclarecer que a oferta pública por alienação de controle é apenas obrigatória para os acionistas titulares de ações com direito a voto, mas o adquirente do controle pode, a seu exclusivo critério e nos termos do edital da oferta lançada, estender a oferta pública a todos os acionistas da companhia, incluindo aqueles sem direito a voto. 
Ademais, o artigo 254-A da Lei das Sociedades por Ações estabelece ainda que toda alienação de controle de companhia aberta realizada por meio de contrato de compra e venda privado deve conter cláusula com condição suspensiva ou resolutiva de o adquirente do controle realizar a oferta pública obrigatória aos acionistas minoritários. Mas qual a diferença entre a condição suspensiva e a condição resolutiva?

A diferença entre tais tipos de condiçõos está relacionada ao fato de o adquirente do controle já ter recebido a titularidade das ações ou não. Assim, se o adquirente já pagou o preço avençado e se o alienante já transferiu as ações que assegurem o controle antes da oferta pública, a condição será resolutiva. Por outro lado, a condição será suspensiva se o alienante não tiver transferido o controle até a realização da oferta pública e, nesse caso, o contrato de compra e venda terá seus efeitos suspensos até a realização da OPA obrigatória direcionada aos minoritários. Sobre este assunto, leciona Roberta Nioac Prado:

\footnotetext{
"Em outras palavras, a cláusula que previr o compromisso de o adquirente realizar a OPA será suspensiva quando não lhe permitir o exercício do controle antes da realização da OPA. Ou seja, a cláusula não lhe proporciona o direito desde logo (desde que assinado o contrato de compra e venda de controle em caráter irrevogável e irretratável).

Ao contrário, esta cláusula será resolutiva se o adquirente do controle puder exercê-lo desde logo (desde que firmado o contrato de alienação de controle irrevogável e irretratável)."
}

Abordamos aqui neste primeiro momento os principais pontos do caput do artigo 254-A. Vamos agora adentrar no estudo no disposto em cada um dos parágrafos de mencionado artigo,

\footnotetext{
${ }^{6}$ PRADO, Roberta Nioac. Oferta Pública de Ações Obrigatória nas S.A. - Tag Along. São Paulo: Quartier Latin, 2005. p. 178-179
} 
começando pelo conceito de alienação de controle para fins de obrigatoriedade de oferta pública de aquisição.

\section{III.1.2. Conceito de Alienação de Controle}

O $\S 1^{\circ}$ do artigo 254-A estabelece que a alienação do controle de companhia aberta pode decorrer de quatro operações distintas decorrentes da transferência, direta ou indireta, de (i) ações integrantes do bloco de controle; (ii) ações vinculadas a acordos de acionistas; (iii) valores mobiliários conversíveis em ações com direito a voto; ou (iv) direitos de subscrição de ações ou outros títulos ou direitos relativos a valores mobiliários conversíveis em ações. Vale notar que tal transferência deve ser feita para terceiros ${ }^{7}$.

Já a Instrução CVM 361/02, que prevê e regula as modalidades de ofertas públicas existentes no Brasil, traz no $\$ 4^{\circ}$ de seu artigo 29 uma definição para alienação de controle, transcrita abaixo. Como podemos notar, tal artigo, diferentemente do $\S 1^{\circ}$ do artigo 254-A, menciona o artigo 116 da Lei das Sociedades por Ações, que conceitua o acionista controlador, para fins de OPA obrigatória por alienação do controle.

\footnotetext{
“\$ $4^{\circ}$ Para os efeitos desta instrução, entende-se por alienação de controle a operação, ou o conjunto de operações, de alienação de valores mobiliários com direito a voto, ou neles conversíveis, ou de cessão onerosa de direitos de subscrição desses valores mobiliários, realizada pelo acionista controlador ou por pessoas integrantes do grupo de controle, pelas quais um terceiro, ou um conjunto de terceiros representando o mesmo interesse, adquira o poder de controle da companhia, como definido no art. 116 da Lei 6.404/76."
}

\footnotetext{
${ }^{7}$ EIZIRIK, Nelson. A Lei das S/A Comentada. Volume III. São Paulo: Quartier Latin, 2011. p. 424
} 
Muitos autores entendem que a transferência de valores mobiliários conversíveis em ações ou de bônus de subscrição ou de ações preferenciais com potencial direito de voto não enseja a obrigação de realizar oferta pública por alienação de controle por si só. Seria necessário o exercício de tais direitos para que a OPA por alienação de controle seja obrigatória. No entanto, esta regra não deve ser absoluta e a situação deve ser analisada com base no caso concreto. Se o preço para o exercício do direito mencionado acima já tiver sido pago e tal exercício for um evento futuro e certo, seria mais seguro ao acionista minoritário que a oferta pública fosse realizada desde logo?

Importante ainda ressaltar que, de acordo com o $\$ 5^{\circ}$ do artigo 29 da Instrução CVM 361/02 ${ }^{8}$, a CVM poderá impor a realização da OPA sempre que entender que houve alienação onerosa do controle de uma companhia aberta, sem prejuízo da definição de alienação de controle prevista no $\$ 4^{\circ}$ do mesmo artigo 29 e mencionada acima.

A alienação de um controle de uma companhia importa, necessariamente, na transferência do poder de dominação sobre a atividade exercida por tal companhia. Assim, é imprescindível que o antigo controlador venda suas ações ou pelo menos parte delas e que um terceiro estranho ao controle adquira tais ações, passando o poder de comando do antigo controlador para o terceiro adquirente. Vale notar que o terceiro neste caso pode ser um acionista que detinha posição minoritária na companhia.

Como resultado do requisito mencionado acima, não configura hipótese de alienação de controle a entrada de um terceiro no bloco

\footnotetext{
${ }^{8}$ Diz o $§ 5^{\circ}$ do artigo 29 da Instrução CVM 361/02: "Sem prejuízo da definição constante do parágrafo anterior, a CVM poderá impor a realização de OPA por alienação de controle sempre que verificar ter ocorrido a alienação onerosa do controle de companhia aberta."
} 
de controle sem que este adquira o poder de comando das atividades sociais ou a reestruturação do controle (ex. a constituição de uma holding entre os sócios de forma a regular melhor o exercício do poder de controle pelos acionistas de uma determinada sociedade), por tais hipóteses não ensejarem a transferência do poder de condução dos negócios sociais para um terceiro.

O conceito de alienação de controle previsto nos dispositivos acima mencionados traz ainda o requisito da onerosidade da operação. De acordo com Nelson Eizirik, "somente pode ser exigida a oferta pública para aquisição das ações pertencentes aos acionistas minoritários nas operações em que haja pagamento, em dinheiro ou em bens",

Ademais, como já mencionamos, é necessária a alienação de todas ou parte das ações dos acionistas que antes dirigiam as atividades sociais. Vale notar, porém, que na vigência do artigo 254, o Conselho Monetário Nacional (“ $\underline{\mathrm{CMN}}$ ”) editou a Resolução CMN 401/76, que conceituava alienação de controle para fins de OPA obrigatória. Tal resolução exigia que o controlador alienante transferisse todas, e não menos que todas, as ações das quais era titular de forma a caracterizar a alienação do controle. No mesmo sentido, quando o controle era exercido por pessoas vinculadas a um acordo de voto, todas as pessoas deveriam alienar suas respectivas ações para transferir tal controle.

Na vigência do atual artigo 254-A, há necessidade apenas que um dos integrantes que integre o grupo de controle aliene suas ações e tal alienação deve importar na transferência do controle

\footnotetext{
${ }^{9}$ EIZIRIK, Nelson. A Lei das S/A Comentada. Volume III. São Paulo: Quartier Latin, 2011. p. 428
} 
independentemente do número de ações alienadas, ou seja, deve entrar na companhia um terceiro que passe a deter o poder de comando de tal companhia. Modesto Carvalhosa explica:

"Caso alguns dos integrantes do acordo ou bloco de controle cedam, a título oneroso, suas posições para terceiro e este assuma uma posição dominante - de acionista majoritário dentro do acordo ou do bloco -, caracterizar-se-á a alienação do controle para efeitos do presente art. 254A, já que presente um novo acionista controlador."

Como consequência do requisito de alienação de pelo menos parte das ações detidas pelo antigo controlador, não restam dúvidas que no caso de aquisição originária do controle de uma companhia aberta não há obrigatoriedade de realizar uma OPA obrigatória por alienação de ações, já que, em outras palavras, não houve necessariamente uma alienação do controle.

A aquisição originária do controle decorre da formação de um bloco de controle no patrimônio do novo controlador, bloco este que não existia antes. Desta forma, o controle não é alienado por uma pessoa ou grupo de pessoas, mas ele se forma por aquisições sucessivas no mercado, pela assinatura de acordos de acionistas ou pela realização de uma oferta pública para aquisição de controle (a OPA voluntária).

A CVM tem entendido que não é necessário também realizar a OPA obrigatória em operações de incorporação, de incorporação de ações, fusão ou cisão, tendo em vista que tais operações visam uma reorganização societária e não uma alienação de controle ${ }^{10}$. A maioria dos doutrinadores também entende que a oferta pública por alienação de controle não seria, a princípio, obrigatória nos casos de

\footnotetext{
${ }^{10}$ Nesse sentido, vide Processo Administrativo CVM RJ 2001/11663, Processo Administrativo CVM RJ 2008/4156 e Memo/SER/GER-1 nº 214/08.
} 
transferência do controle minoritário, mesmo que o artigo 116, que define o acionista controlador, preveja tal modalidade de controle ${ }^{11}$.

Com relação à obrigatoriedade de realização de uma OPA obrigatória para transferência do controle minoritário, Roberta Nioac Prado observa que, embora a atual Lei das Sociedades por Ações e a Instrução CVM 361/02 não contemplarem esta hipótese de poder de controle para fins de OPA, a CVM pode obrigar a oferta pública sempre que verificar ter ocorrido uma alienação onerosa do controle minoritário de companhia aberta, por força do disposto no $\S 5^{\circ}$ do artigo 29 da Instrução CVM 361/02.

Um aspecto controvertido na doutrina e na jurisprudência diz respeito ao conceito de poder de controle para fins de aplicação do artigo 254-A. Segundo Roberta Nioac Prado, o poder de controle é aquele detido pelo acionista controlador, qualificado nos termos do artigo 116 da Lei das Sociedades por Ações. Nesse mentido sentido, manifesta-se Modesto Carvalhosa: "o titular do poder de controle, tal como legalmente definido (art. 116), constitui inequivocadamente o acionista controlador, para os efeitos da lei societária e da regulamentação administrativa da $\operatorname{CVM}\left(\S 3^{\circ}\right) . "$

Consubstancia o entendimento exposto acima o fato de o $\$ 4^{\circ}$ do artigo 29 da Instrução CVM 361/02 fazer referência ao artigo 116 para definição do poder de controle. De fato, não se pode ignorar a

\footnotetext{
${ }^{11}$ Em sentido contrário, Erik Frederico Oioli entende que não há qualquer fundamento para afastar o controle diluído ou minoritário da incidência do artigo 254-A da Lei das Sociedades por Ações. Segundo este autor, os argumentos que sustentam que o controle para fins de incidência de OPA não seria o mesmo do controle do artigo 116 não deveriam prosperar, por não fazer sentido a existência de conceitos de controle diferentes no mesmo ordenamento jurídico. Sobre este assunto, vide OIOLI, Erik Frederico. Obrigatoriedade do Tag Along na Aquisição de Controle Diluído. In: ADAMEK, Marcelo Vieira von (coord.). Temas de Direito Societário e Empresarial Contemporâneos. São Paulo: Malheiros, 2011. p. $316-326$
} 
definição societária de acionista controlador, porém a interpretação do artigo 254-A da Lei das Sociedades por Ações e do artigo 29 da Instrução CVM 361/02 deve considerar que o artigo 116 foi elaborado com o objetivo de responsabilização do acionista controlador e não para fins de caracterizar a alienação de controle.

O assunto tem suma importância em razão dos dois requisitos necessários para caracterizar o acionista controlador, nos termos das alíneas (a) e (b) do artigo 116 da Lei das Sociedades por Ações, cujos conceitos serão detalhados no Capítulo IV deste trabalho: (a) titularidade de direitos de sócio que assegurem, de modo permanente, a maioria dos votos nas deliberações da assembleia geral e o poder de eleger a maioria dos administradores da companhia; e, cumulativamente, (b) uso efetivo do poder para dirigir as atividades sociais e orientar o funcionamento dos órgãos da companhia.

Não há qualquer questionamento com relação à necessidade de observância do requisito (a) acima para caracterização da alienação de controle. Se houver segurança que as ações transferidas conferirão ao novo acionista a maioria dos votos nas deliberações sociais, de modo permanente, há o cumprimento do primeiro requisito exigido pela legislação.

Já com relação ao requisito previsto no item (b) acima, oa CVM já se manifestou pela não necessidade de uso efetivo do poder para fins de alienação do controle, conforme o voto proferido pelo diretor Pedro Oliva Marcílio de Souza no caso CBD, descrito no Capítulo V abaixo. Segundo tal diretor, o $\$ 4^{\circ}$ do artigo 29 da Instrução CVM 361 fala apenas na transferência de valores mobiliários e, portanto, ao referir-se ao artigo 116 da Lei das 
Sociedades por Ações, quis referir-se apenas à alínea "a" de mencionado artigo.

No entanto, Roberta Nioac Prado defende que a Instrução CVM 361/02 obriga a oferta pública apenas quando houver alienação de ações de propriedade de acionistas que estão no efetivo exercício do controle, não considerando a alienação de ações de propriedade de acionistas que têm potencial para exercer o controle. Nas palavras da autora:

"Assim, para efeito de incidência do art. 254-A da LSA de 1976, o bloco de ações objeto de uma cessão privada de controle deve necessariamente consubstanciar um poder de controle efetivamente exercido pelo acionista alienante, não bastando, por exemplo, consubstanciar bloco de ações majoritário." 12

Nelson Eizirik, por sua vez, manifesta-se no sentido de que o objetivo da regra contida no artigo 116 da Lei das Sociedades por Ações foi de facilitar a responsabilização do acionista controlador por seus atos abusivos e, então, não pode ser utilizado para a interpretação dos casos de alienação de controle. Esse entendimento é consubstanciado no fato de o $\S^{\circ}$ do artigo 254-A não fazer qualquer referência ao artigo 116. Segundo o autor, "embora o alienante não exerça efetivamente o controle, ele é titular de um bloco de controle, cuja alienação permite ao adquirente passar a exercer, de imediato e por sua exclusiva vontade, as prerrogativas do controle acionário."13

Nesse mesmo sentido entende Alfredo Sérgio Lazzareschi $\mathrm{Neto}^{14}$. Analisando o mencionado voto do Diretor Pedro Oliva

\footnotetext{
${ }^{12}$ PRADO, Roberta Nioac. Op. cit. p. 128.

${ }^{13}$ EIZIRIK, Nelson. Aquisição de Controle Minoritário. Inexigibilidade de Oferta Pública. In: CASTRO, Rodrigo R. Monteiro de; AZEVEDO, Luís André N. de Moura Azevedo. Poder de Controle e Outros Temas de Direito Societário e Mercado de Capitais. São Paulo: Quartier Latin, 2010. p. 182.

${ }^{14}$ NETO, Alfredo Sérgio Lazzareschi. Lei das Sociedades por Ações Anotada. $3^{\mathrm{a}}$ edição. São Paulo: Saraiva, 2010. p. 617.
} 
Marcílio de Souza, se o alienante é titular da maioria das ações com direito a voto, mas não exerce tais direitos, ele não será considerado acionista controlador para fins de responsabilidade do artigo 116. No entanto, caso ele aliene suas ações e o adquirente tenha interesse em exercer o controle da companhia, ele poderá fazê-lo e, portanto, deve ser considerado o prêmio de controle no preço da aquisição. Haveria, assim, alienação do poder de controle.

A princípio o entendimento do Diretor Pedro Oliva Marcílio de Souza e do ilustre Nelson Eizirik consiste no mais coerente para a situação. $\mathrm{O}$ fato de o acionista ter a propriedade das ações que lhe garantem maioria dos votos nas deliberações sociais é por si só um poder e, como tal, tem o seu valor patrimonial. Tal acionista pode não exercer este poder que lhe é conferido, mas ele sempre terá a possibilidade de exercê-lo quando achar conveniente ou quando the interessar. Desta forma, ele possui o poder de controle, mas o seu exercício depende da conveniência da situação.

Nesse sentido, como ele tem o poder de controle, ele pode aliená-lo para qualquer terceiro, tendo este terceiro a possibilidade de exercer o poder ou não. Fato é que o poder de controle foi transferido e, assim, deve ser realizada a OPA obrigatória por alienação de controle. O requisito do uso efetivo do poder foi inserido na legislação societária, como bem ressaltaram Nelson Eizirik e o diretor Pedro Oliva Marcílio de Souza, com o objetivo de responsabilização do acionista controlador, pois só pode ser responsabilizado por abuso de poder aquele que de fato exerce tal poder.

Assim, se o adquirente de ações que lhe conferem a maioria nas deliberações sociais resolver exercer o poder que lhe é conferido por tais ações, diferentemente do possuidor anterior, há uma efetiva 
alteração de controle da companhia e, consequentemente, os acionistas minoritários deverão ter que se submeter às regras de um terceiro que era estranho ao controle da sociedade. Justifica-se, portanto, a obrigatoriedade da OPA para servir de porta de saída para os minoritários.

\section{III.1.3. O Prêmio dos Minoritários}

Analisando ainda o artigo 254-A, faz-se necessário tecer comentários acerca do $\S 4^{\circ}$ de dito dispositivo legal, que estabelece a possibilidade de o adquirente do controle pagar um prêmio aos acionistas minoritários para a permanência na companhia a título de recompensa pelo não exercício do direito de tag along.

Importante notar que o pagamento do prêmio aqui mencionado é uma faculdade do adquirente do controle e não se configura como uma alternativa à realização da OPA obrigatória, mas é cumulativo a esta. Se previsto no edital da oferta pública, o pagamento do prêmio deve ser estendido a todos os acionistas minoritários que não aceitaram a oferta pública por alienação do controle.

Conforme estabelece o $\S 4^{\circ}$ do artigo 254-A, o valor do prêmio deve ser igual a, no mínimo, a diferença entre o valor de mercado das ações e o valor pago pelas ações do alienante controlador. No entanto, como o prêmio é facultativo, pode o adquirente do controle estabelecer que o valor do prêmio será menos do que tal diferença. Segundo Norma Parente, "caso o prêmio seja menor do que o previsto em lei, nada impede que o acionista assim o aceite" ${ }^{15}$, já que

\footnotetext{
${ }^{15}$ PARENTE, Norma. Principais Inovações Introduzidas pela Lei $\mathrm{m}^{\circ} 10.303$, de 31 de outubro de 2001, à Lei das Sociedades por Ações. In: LOBO, Jorge (coord.). Reforma da
} 
ele poderia também optar por permanecer como acionista da companhia ainda que não houvesse a previsão de pagamento de prêmio.

Esta faculdade trazida pela reforma da Lei das Sociedades por Ações possui vantagens tanto para o adquirente do controle como para os acionistas minoritários. Conforme explicou Norma Parente ${ }^{16}$, para o adquirente, o pagamento do prêmio é vantajoso por ele ter que desembolsar apenas esta diferença e não o valor total das ações. Já o acionista minoritário recebe o valor do prêmio, usufruindo do valor de controle e permanece em uma companhia cujas ações vão continuar com liquidez.

\section{III.1.4. Análise das Regras de OPA no Direito Comparado}

A OPA obrigatória constitui instituto previsto no ordenamento jurídico de diversos países, inclusive os países da União Européia. Desta forma, é essencial no estudo deste caso fazer uma comparação das regras e princípios para a obrigatoriedade de realização de oferta pública por alienação de controle.

A Directiva 2004/25/CE do Parlamento Europeu e do Conselho da União Européia estabeleceu, em 21 de abril de 2004, que deverá ser realizada uma oferta pública de aquisição obrigatória sempre que algum acionista passe a deter determinada quantidade de ações que lhe confira o poder de controle de uma companhia. Tal Directiva, porém, não estabeleceu o percentual do capital social de uma companhia que considera suficiente para que determinado

Lei das Sociedades Anônimas: inovações e questões controvertidas da Lei $n^{\circ} 10.303$, de 31.10.2011. $1^{\text {a }}$ edição. Rio de Janeiro: Forense, 2002. p. 42

${ }^{16}$ Idem. Op. cit. p. 42 
acionista passe a deter o controle. No entanto, a maioria dos países estabeleceu a obrigatoriedade de realização da oferta pública quando um acionista passar a deter $30 \%$ do capital votante de uma companhia.

Na Inglaterra, o City Code on Takeovers and Mergers, que se tornou obrigatório com a promulgação da Directiva 2004/25/CE, tem como princípio básico o tratamento igualitário entre os acionistas minoritários e os controladores de determinada companhia. Desta forma, é obrigatória a realização de uma oferta pública (mandatory tender offer) caso determinado acionista passe a deter $30 \%$ do capital social da uma companhia, sendo que o preço a ser pago em tal oferta deverá ser igual ao preço pago ao antigo controlador. Garante-se, assim, aos minoritários um direito de tag along de 100\%, diferente do Brasil em que os minoritários só têm direito a $80 \%$ do preço pago ao alienante.

Da mesma forma que na Inglaterra, o princípio de igualdade de oportunidades entre os acionistas é o princípio norteador do direito societário francês. A oferta pública deve ser realizada, então, no mesmo preço pago para a cessão do controle e a sua obrigatoriedade é disparada quando determinado acionista atinge o percentual de $30 \%$ do capital votante da companhia.

Ainda sobre o direito francês, dois aspectos são importantes: (i) os acionistas devem comunicar ao mercado toda vez que atingirem um percentual relevante no capital social de uma companhia, de acordo com os números previstos na legislação que variam de $5 \%$ a $66,6 \%$, sob pena de perderem seus direitos de voto; e (ii) a oferta pública por alienação do controle é destinada a todos os acionistas, detentores de ações com e sem direito de voto. 
Os Estados Unidos, porém, não previram na sua legislação societária, resumida pelo Williams Act de 1968, o instituto da oferta pública obrigatória por alienação do controle de uma companhia. Isto decorre do princípio que rege o direito societário norte americano de que os acionistas têm liberdade para alienar as suas ações como e da forma que desejarem, sem que os demais acionistas tenham direito sobre o ágio eventualmente pago ao alienante.

Nesse sentido, não faz diferença nos Estados Unidos um acionista vender ações que garantem o controle de uma companhia ou não: os demais acionistas de tal companhia não terão direito ao prêmio eventualmente pago pelo controle. Importante ressaltar que dificilmente nos Estados Unidos o controle de uma companhia é alienado por meio de uma operação privada, tendo em vista a alta dispersão acionária deste país. Desta forma, é muito mais comum que o controle seja adquirido por meio de uma oferta hostil do que por meio de uma negociação privada.

Feita essa análise com o direito comparado acerca da OPA obrigatória, podemos entrar na recente discussão entre os grandes pensadores do direito societário brasileiro acerca da implementação no Brasil de um critério objetivo para definir o poder de controle para fins de obrigatoriedade de oferta pública.

Os que entendem que deve ser adotado tal parâmetro, tal como é feito no direito europeu, argumentam pela segurança jurídica do mercado de capitais que decorreria de um critério objetivo. Além disso, com o percentual que dispara a necessidade de OPA obrigatória fixado em, por exemplo, $30 \%$, a transferência do controle minoritário ensejaria a necessidade de uma oferta pública, o que pode 
não ocorrer atualmente no direito brasileiro, dependendo dos direitos do minoritário em acordo de acionistas.

Por outro lado, há quem defenda que o critério objetivo não é a melhor solução para o mercado de capitais brasileiro, tendo em vista que a maioria do nosso capital ainda é concentrado, sendo o controle exercido por acionistas majoritários ou vinculados por acordos de acionistas. O critério objetivo é adotado em países com cenário econômico e organizações societárias diferentes, com alta dispersão acionária e capital pulverizado.

Ambos os argumentos têm vantagens e desvantagens. De fato, a adoção de um critério objetivo traz mais segurança jurídica para o mercado de capitais, com menos abertura para discussão sobre a necessidade ou não de oferta pública em determinado caso. No entanto, tal critério objetivo é eficiente em companhias com capital pulverizado, em que o controle é exercido por minoritários.

A economia do Brasil está evoluindo e, consequentemente, o mercado de capitais está se tornando mais complexo. Companhias com capital pulverizado e controle minoritário estão começando a surgir, mas ainda não são a regra. Desta forma, mais razoável seria esperar que a estrutura das companhias brasileiras se modifique antes de alterar a legislação societária e adotar um critério objetivo para aumentar consideravelmente o número de OPAs e o custo das transações com companhias abertas no Brasil. 


\section{III.2. A Oferta Pública Hostil}

De acordo com o estudado no Capítulo II acima, a Vivendi tinha a intenção de realizar, e a Telefônica realizou, uma oferta pública para aquisição do controle da GVT, aqui chamada de OPA voluntária. Tal instituto está previsto no artigo 257 da Lei das Sociedades por Ações, abaixo transcrito, além de ser regulado pela Instrução CVM 361/02, conforme alterada.

"Art. 257. A oferta pública para aquisição de controle de companhia aberta somente poderá ser feita com a participação de instituição financeira que garanta o cumprimento das obrigações assumidas pelo ofertante.

$\S 1^{\circ}$ Se a oferta contiver permuta, total ou parcial, dos valores mobiliários, somente poderá ser efetuada após prévio registro na Comissão de Valores Mobiliários.

$\S 2^{\circ}$ A oferta deverá ter por objeto ações com direito a voto em número suficiente para assegurar o controle da companhia e será irrevogável.

$\S 3^{\circ}$ Se o ofertante já for titular de ações votantes do capital da companhia, a oferta poderá ter por objeto o número de ações necessário para completar o controle, mas o ofertante deverá fazer prova, perante a Comissão de Valores Mobiliários, das ações de sua propriedade.

$\S 4^{\circ}$ A Comissão de Valores Mobiliários poderá expedir normas sobre oferta pública de aquisição de controle."

\section{III.2.1. Características Gerais}

A OPA voluntária surgiu na Inglaterra e se consolidou nos Estados Unidos, como veremos mais adiante, como uma alternativa para a aquisição do controle de uma companhia. Antes de tal instituto, apenas era possível adquirir o controle de uma companhia por meio de negociação privada com os acionistas ou pela escalada em bolsa. 
Tanto a negociação privada como a escalada em bolsa são formas de aquisição do controle de uma companhia muito onerosas para o adquirente, principalmente quando o capital de tal companhia está disperso no mercado e os administradores se manifestam contrariamente à aquisição. A OPA voluntária surgiu então como uma forma do potencial adquirente oferecer a todos os acionistas da companhia um determinado preço por suas ações, preço este geralmente acima do valor de mercado.

Conforme ensina Gustavo Santamaria Carvalhal Ribas ${ }^{17}$, a aquisição hostil consiste em um mecanismo pelo qual o ofertante ignora a administração de determinada companhia e propõe direta e publicamente a todos os acionistas de tal companhia a aquisição de suas ações por determinado preço e durante um certo período.

Já Modesto Carvalhosa define a OPA voluntária como uma "declaração unilateral de vontade" por meio da qual o adquirente se compromete a adquirir um valor mobiliário específico "a um preço determinado e segundo cláusulas e condições também determinadas." ${ }^{18}$

De acordo com as definições apresentadas acima, conclui-se que a oferta lançada no âmbito do artigo 257 da Lei das Sociedades por Ações é firme e irrevogável e constitui um compromisso assumido pelo ofertante em adquirir determinadas ações se as condições impostas e previstas no edital da OPA forem cumpridas. Não se trata, portanto, de mera intenção.

\footnotetext{
${ }^{17}$ RIBAS, Gustavo Santamaria Carvalhal. Das Aquisições Hostis na Prática NorteAmericana e a Perspectiva Brasileira. Revista de Direito Mercantil, Industrial, Econômico e Financeiro. São Paulo: Malheiros, n. 141. p.124. jan./mar. 2006.

${ }^{18}$ CARValhosa, Modesto. Oferta Pública de Aquisição de Ações. Rio de Janeiro: IBMEC, 1979. p. 24.
} 
Ademais, a OPA ora em análise pode ter duas finalidades diferentes: (i) a aquisição do controle de determinada companhia, quando o ofertante ainda não faz parte do quadro acionário de tal companhia; e (ii) o reforço do controle acionário, quando o ofertante já é titular de ações que lhe asseguram o poder de controle.

Importante notar que apesar de a OPA voluntária para a aquisição do controle ser comumente conhecida como oferta hostil, ela nem sempre será de fato hostil, podendo também ser considerada uma oferta amigável. A oferta será hostil quando ela não for desejada pelos administradores e acionistas da companhia alvo da oferta. Ao contrário, se há um consenso entre tais administradores e acionistas com relação aos termos da oferta a ser lançada ou se esta é atrativa para os interesses da companhia, tal como ocorreu com a Vivendi e os acionistas controladores da GVT, a oferta será considerada amigável. Não há qualquer diferença no procedimento da OPA no caso de ela ser amigável ou hostil.

A oferta pública para a aquisição de controle traz vantagens tanto para o adquirente de tal controle como para os acionistas da companhia alvo. Ao adquirente, possibilita que ele faça uma oferta destinada aos acionistas de uma companhia sem ter que entrar em negociação privada com os administradores ou com eventual controlador. Além disso, como veremos adiante, o ofertante pode condicionar a sua oferta à aquisição de pelo menos $51 \%$ das ações da companhia alvo, tal como previsto no edital da Telefônica, precisando desembolsar os recursos para o pagamento das ações apenas se a oferta atingir este percentual e, portanto, o adquirente conseguir o poder de controle. 
Por outro lado, os acionistas da companhia alvo também se beneficiam com a realização de uma oferta pública para a aquisição de controle, tendo em vista que a oferta é lançada em condições de igualdade para todos os acionistas, podendo variar apenas de acordo com as espécies de classes. Portanto, todos os destinatários da oferta se beneficiam com o valor do prêmio de controle embutido no preço da oferta.

As companhias alvo de ofertas públicas para aquisição de controle são aquelas cujo capital encontra-se disperso no mercado, de forma que o controle de tal companhia é exercido ou por minoritários (controle minoritário) ou pela própria administração. Para companhias com essas características, a OPA voluntária constitui um método mais barato e eficiente para aquisição do seu controle.

Ademais, como o ofertante não possui informações detalhadas sobre os negócios realizados pela companhia e normalmente não conduz uma auditoria legal antes do lançamento de sua oferta, outras características são consideradas para que uma companhia se torne alvo de OPAs voluntárias, tais como: liquidez no mercado, valor da cotação das ações em bolsa abaixo do valor de mercado, elevada capacidade de fluxo de caixa, capital pulverizado e inexistência de poison pills.

O principal ponto de discussão nas OPAs hostis diz respeito à competência da administração da companhia em utilizar mecanismos de defesa com o objetivo de frustrar tais ofertas; ou seja, a administração teria o poder de decidir sobre a aceitação ou não da oferta. A proporção deste ponto é ainda mais relevante, tendo em vista que, quando adquirido o controle de uma companhia por meio de OPA, os seus antigos administradores são normalmente 
realocados, por entender o adquirente que o preço de negociação das ações de tal companhia estaria abaixo do valor de mercado por problema de ineficiência na administração, o que gera um evidente conflito de interesses na administração.

Vale ainda mencionar que, de acordo com o caput do artigo 257 da Lei das Sociedades por Ações, a OPA voluntária somente poderá ser feita com a participação de instituição financeira que garanta o cumprimento das obrigações assumidas pelo ofertante. Além disso, esta modalidade de oferta pública não se sujeita, via de regra, a registro prévio perante a CVM, devendo esta apenas ser comunicada da oferta dentro de 24 horas da publicação do edital. Excetua-se desta regra o caso de a oferta pública conter proposta de permuta de valores mobiliários, de acordo com o $\S 1^{\circ}$ do mencionado artigo 257 .

\section{III.2.2. Poison Pills}

Passaremos agora a uma breve análise acerca das medidas defensivas à tomada de controle de companhias abertas, conhecidas como poison pills. Apesar de as poison pills serem uma das medidas defensivas possíveis para se evitar a realização de uma oferta hostil, talvez a mais conhecida, utilizaremos tal termo neste trabalho de uma forma ampla, em equivalência ao termo "medidas defensivas". De acordo com o Black's Law Dictionary ${ }^{19}$, poison pill é:

"A corporation's defense against an unwanted takeover bid whereby shareholders are granted the right to acquire equity or debt securities at a favorable price to increase the bidder's acquisition costs."

\footnotetext{
${ }^{19}$ GARNIER, Bryan A. Black's Law Dictionary. $9^{\text {a }}$ edição. Saint Paul: West, 2009. p. 1275.
} 
Em outras palavras, as medidas defensivas são adotadas por companhias de forma a prevenir ou evitar que o controle de tal companhia seja adquirido por um terceiro por meio de uma oferta pública para aquisição de controle. Elas também são conhecidas como medidas "afasta-tubarão" (shark repellents) ou disposições "porco-espinho" (porcupine provisions).

O estudo de tais medidas defensivas é essencial neste trabalho na medida em que uma das condições para a realização da potencial oferta voluntária pela Vivendi e para o lançamento da OPA hostil pela Telefônica era a dispensa das poison pills previstas no estatuto social da GVT. Os artigos 43 e 44 do estatuto social da GVT estabeleciam o seguinte:

"Artigo 43. Qualquer Acionista Adquirente, que adquira ou se torne titular de ações de emissão da Companhia em quantidade igual ou superior a $15 \%$ (quinze por cento) do total das ações de emissão da Companhia deverá, (i) obter autorização prévia da Agência Nacional de Telecomunicações - ANATEL, nos termos da legislação aplicável, e (ii) no prazo máximo de 30 (trinta) dias a contar da data de aquisição ou do evento que resultou na titularidade de ações em quantidade igual ou superior a $15 \%$ (quinze por cento) do total de ações de emissao da Companhia, efetivar, conforme o caso, uma oferta pública de aquisição de ações ("OPA") da totalidade das ações de emissão da Companhia, observando-se o disposto na regulamentação aplicável da CVM, o Regulamento de Listagem do Novo Mercado, outros regulamentos da BOVESPA e os termos deste artigo.

$\S 1^{\circ}$. A OPA deverá ser: (i) dirigida indistintamente a todos os acionistas da Companhia e detentores de direitos ou opções conversíveis em ações da Companhia e não poderá estar condicionada a números mínimos de aceitação; (ii) efetivada em leilão a ser realizado na BOVESPA; (iii) lançada pelo preço determinado de acordo com o previsto no $\S 2^{\circ}$ deste artigo; e (iv) paga à vista, em moeda corrente nacional, contra a aquisição na OPA de ações de emissão da Companhia.

$\S 2^{\circ}$. O preço de aquisição na OPA de cada ação de emissão da Companhia não poderá ser inferior ao maior valor entre (i) $125 \%$ (cento e vinte e cinco por cento) da cotação unitária mais alta atingida pelas ações de emissão da Companhia durante o período de 12 (doze) meses anterior à realização da OPA em qualquer bolsa de valores em que as ações da Companhia foram negociadas; (ii) $125 \%$ do preço unitário mais alto pago 
pelo Acionista Adquirente, a qualquer tempo, para uma ação ou lote de ações de emissão da Companhia; (iii) o valor econômico apurado em laudo de avaliação, com base nos critérios, adotados de forma isolada ou combinada, de patrimônio líquido contábil, de patrimônio líquido avaliado a preço de mercado, de fluxo de caixa descontado, de comparação por múltiplos, de cotação das ações no mercado de valores mobiliários, ou com base em outro critério aceito pela Comissão de Valores Mobiliários. (...)"

"Artigo 44. Qualquer Acionista Adquirente que tenha subscrito e/ou adquirido ações de emissão da Companhia, em quantidade igual ou superior a 9,9 (nove vírgula nove por cento) do número total de Ações em Circulação da Companhia e que deseje realizar uma nova aquisição de ações de emissão da Companhia em bolsa de valores, estará obrigado a, previamente a cada nova aquisição, comunicar por escrito à Companhia e ao diretor do pregão da BOVESPA, através de sociedade corretora pela qual pretenda adquirir as ações, sua intenção de adquirir outras ações de emissão da Companhia, com antecedência mínima de 3 (três) dias úteis da data prevista para a realização da nova aquisição de ações, de tal modo que o diretor possa previamente convocar um leilão de compra a ser realizado em pregão da BOVESPA do qual possam participar terceiros interferentes e/ou eventualmente a própria Companhia, observados sempre os termos da legislação vigente, da regulamentação da CVM e os regulamentos da BOVESPA aplicáveis. (...)”

Como se pode depreender dos artigos 43 e 44 do estatuto social da GVT, tal companhia optou por inserir cláusulas de proteção à dispersão acionária como forma de prevenir a aquisição do seu controle. Tais cláusulas configuram como umas das espécies de medidas defensivas e são totalmente diferentes das poison pills, em seu sentido estrito.

De fato, a cláusula de proteção à dispersão acionária é a medida defensiva mais adotada pelas companhias brasileiras. São duas as disposições estatutárias que prevalecem no Brasil, sendo as duas utilizadas de forma separada ou em conjunto. Chamaremos aqui tais disposições como "Tipo A" e "Tipo B", a mesma denominação utilizada por João Pedro Barroso do Nascimento ${ }^{20}$.

\footnotetext{
${ }^{20}$ NASCIMENTO, João Pedro Barroso do. Medidas Defensivas à Tomada de Controle de Companhias. São Paulo: Quatier Latin, 2011. p. 149-161.
} 
A disposição considerada "mais pesada" é a "Tipo A", que prevê que qualquer acionista ou terceiro que se tornar titular, seja por meio de aquisição ou outro meio, de uma quantidade igual ou superior a determinado percentual do total de ações, deverá realizar uma oferta pública de aquisição de ações para adquirir a totalidade das ações de emissão da companhia.

Como podemos perceber, o estatuto social da GVT estabelece no seu artigo 43 a cláusula de proteção à dispersão acionária do “Tipo A”. A disposição estatutária da GVT vai além da obrigatoriedade de se realizar a oferta pública para aquisição da totalidade das ações de dita companhia, impondo o preço de, pelo menos, $125 \%$ do preço pago pelo acionista adquirente pelas ações da GVT.

Já as disposições denominadas “Tipo B” possuem consequências mais brandas para o acionista adquirente, determinando que aquele que se tornar titular, seja por meio de aquisição ou outro meio, de uma quantidade igual ou superior a determinado percentual do total das ações, tal acionista deverá comunicar ao diretor de relação com investidores da companhia e/ou ao diretor do pregão da bolsa de valores, por meio da sociedade corretora pela qual pretenda adquirir ações, sua intenção de adquirir outras ações emitidas pela companhia. Com tal aviso, o diretor do pregão poderá convocar um leilão de compra no qual possam participar terceiros interferentes e até a própria companhia.

Nota-se que a disposição do “Tipo B” também está inserida no estatuto social da GVT, conforme o artigo 44 acima transcrito. Desta forma, a GVT adota tanto a cláusula de proteção à dispersão acionária de "Tipo A" para os acionistas titulares de ações iguais ou superiores a $15 \%$ do capital da companhia, quanto da disposição de "Tipo B", 
para os acionistas titulares de ações iguais ou superiores a 9\% do capital da companhia.

A adoção da cláusula de "Tipo A", principalmente com relação ao preço fixado, onera muito o aumento de participação acionária na GVT. Objetiva-se, claramente, evitar uma oferta hostil para a tomada de controle da GVT. Por tal motivo, tanto a Vivendi quanto a Telefônica incluíram a dispensa de observância de tais artigos como condição para a realização de suas ofertas públicas para tomada de controle.

Em assembleia geral extraordinária realizada em 3 de novembro de 2009, os acionistas da GVT concordaram pela dispensa dos artigos 43 e 44 do seu estatuto social para aquisições de ações da Companhia que possuam as seguintes características: (i) a liquidação financeira deverá ocorrer até 28 de fevereiro de 2010; (ii) o preço a ser pago será de no mínimo $\mathrm{R} \$ 48,00$ por ação; (iii) o pagamento será em dinheiro; e (iv) o ofertante (a) deverá possuir capacidade financeira para a aquisição de $100 \%$ do capital social da Companhia por um preço mínimo de $\mathrm{R} \$ 48,00$ por ação; e (b) deverá ser operador ou provedor de serviços de telefonia fixa, móvel ou de banda larga no Brasil ou no exterior, diretamente ou por intermédio de sua(s) subsidiárias, controlada(s) ou coligada(s), registrando-se a abstenção de voto da acionista Telefônica.

Vale ainda mencionar neste trabalho que o estatuto social da GVT previu sanções ao descumprimento das cláusulas de proteção à dispersão acionária, devendo ser convocada uma assembleia geral para deliberar acerca da suspensão dos direitos do acionista que descumprir tais regras. 


\section{III.2.3. Análise da Oferta Hostil no Direito Comparado}

Nos mesmos termos vistos na análise do direito comparado para as ofertas públicas de alienação de ações, a Directiva 2004/25/CE do Parlamento Europeu estabelece as regras e procedimentos que devem ser adotados nas ofertas públicas para aquisição do controle de uma companhia sujeita a legislação dos Estados-membros. O artigo $2^{\circ}$ (1) (a) de tal Directiva define a oferta pública de aquisição:

“«Oferta pública de aquisição» ou «oferta»: uma oferta pública (que não pela sociedade visada) feita aos titulares de valores mobiliários de uma sociedade para adquirir a totalidade ou uma parte desses valores mobiliários, independentemente de essa oferta ser obrigatória ou voluntária, na condição de ser subsequente à aquisição do controlo da sociedade visada ou ter como objectivo essa aquisição do controlo nos termos do direito nacional"

Um dos princípios previstos na Directiva é de suma relevância para as ofertas voluntárias: o órgão da administração deve agir de acordo com o interesse da companhia e não pode impedir que os acionistas decidam sobre o mérito da oferta. A Directiva adotou, assim, a posição de neutralidade dos administradores. No entanto, esta regra não deve ser necessariamente observada pelos EstadosMembros, podendo um determinado país permitir que o administrador adote medidas defensivas contra ofertas hostis.

A primeira regra sobre os takeovers bids surgiu na Inglaterra em 1929. Atualmente, o direito inglês adota o City Code on Takeovers and Mergers para regular as regras das ofertas públicas. Nesse sentido, dispõe o City Code que a oferta deve ser comunicada primeiro aos administradores, os quais a levarão ao conhecimento dos acionistas e do órgão regulador (Takeover Panel). No entanto, o City Code estabelece que os administradores devem submeter a adoção de 
qualquer medida preventiva que frustre uma oferta hostil à prévia aprovação dos acionistas.

A França seguiu a orientação da Directiva Européia, adotando o princípio da neutralidade dos administradores. No entanto, cabe ressalvar que a legislação de tal país permite que os administradores emitam títulos de forma a diluir o ofertante. Tal emissão, porém, precisa da prévia autorização dos acionistas.

As ofertas voluntárias são muito usuais nos Estados Unidos, onde o mercado acionário encontra-se altamente diluído. Nesse sentido, as tender offers são reguladas pelo Securities Exchange Act de 1934, conforme alterado pelo Williams Acts de 1968. Na legislação americana, não há uma definição de tender offers, cabendo a doutrina e a jurisprudência estabelecerem os fatores e características de tais ofertas. Nesse sentido:

"In classic terms, a tender offer involves a public announcement by a bidder - through newspaper ads and the like - of a willingness to purchase shares of the target company for some limited period of time directly from target shareholders at a premium over the prevailing market price. ${ }^{21}$

Como podemos perceber, a definição clássica de oferta pública voluntária trazida pela doutrina norte-americana muito se assemelha com a definição brasileira deste instituto. A jurisprudência e doutrina dos Estados Unidos têm listado ainda alguns fatores que ajudam na definição de tender offer, tais como: (i) se a oferta tem como objeto porcentagem expressiva do capital da companhia; (ii) se os termos da oferta são firmes e não negociáveis; (iii) se o preço da oferta é superior ao preço da cotação em bolsa de valores, dentre outros

${ }^{21}$ COX, James D.; HILlMAN, Robert W.; LANGEVOORT, Donald C. Securities Regulation: Cases and Material. $5^{\text {a }}$ edição. Nova York: Aspen Publishers, 2006. p. 978 
fatores. Ademais, os diretores da companhia devem se manifestar sobre a oferta, recomendando-a ou rejeitando-a para os acionistas.

\section{III.3. A Oferta Pública Concorrente}

Quando do lançamento da OPA voluntária ou hostil pela Telefônica para a aquisição do controle da GVT, o mercado passou a esperar a realização de uma oferta concorrente pela Vivendi, tendo em vista que tanto a GVT quanto a Vivendi já tinham se manifestado sobre o interesse da companhia francesa em adquirir o controle da companhia brasileira.

A OPA concorrente, prevista no artigo 262 da Lei das Sociedades por Ações, permite que um terceiro formule uma oferta pública que tenha por objeto as ações abrangidas por outra oferta pública que esteja em curso. Assim, a Vivendi lançaria uma oferta tendo por objeto as ações da GVT, abrangidas pela oferta já lançada pela Telefônica e cujo leilão já estava marcado.

Aplicam-se à OPA concorrente os mesmos requisitos e procedimentos da OPA com que concorrer, inclusive com relação ao registro perante a CVM. Além disso, o $§ 1^{\circ}$ do mencionado artigo 262 estabelece que serão nulas as ordens de venda que já tenham sido firmadas em aceitação da primeira oferta. Nesse sentido e de acordo com o $\$ 2^{\circ}$ do dispositivo legal, é facultado ao primeiro ofertante prorrogar o prazo de sua oferta de forma a coincidir o seu leilão com o da sua concorrente.

Com relação ao $\S 1^{\circ}$, quis o legislador que o acionista que já havia aceitando a primeira oferta se manifestasse confirmando a sua 
adesão à primeira oferta ou aceitando a oferta concorrente. Cumpre esclarecer que em nenhum momento quis o legislador obrigar que o acionista aceitasse a oferta concorrente, mas apenas que ele confirmasse o seu aceite após o lançamento da oferta concorrente.

Uma das características essenciais da OPA concorrente é que ela deve ser lançada por preço no mínimo 5\% superior ao da OPA com que concorrer, de acordo com o disposto no artigo $13, \S 3^{\circ}$ da Instrução CVM 361/02. Além disso, ela deve ser lançada em até 10 dias antes da data prevista para a realização do leilão da oferta pública com a qual concorrer ( $\$ 2^{\circ}$ deste mesmo artigo).

Além disso, tanto o ofertante inicial quanto o ofertante concorrente podem aumentar o preço de suas ofertas tantas vezes quanto julgarem necessário, não se aplicando no caso de OPA concorrente a regra de que o ofertante pode aumentar o preço uma única vez, nos termos do artigo $262, \S 1^{\circ}$ da Lei das Sociedades por Ações. De fato, a aplicação desta regra da Lei das Sociedades por Ações seria injusta em um cenário de concorrência entre duas empresas para a tomada do controle de uma terceira.

Importante notar que a OPA concorrente é muitas vezes utilizada como uma forma de defesa da administração da companhia contra ofertas hostis. Em alguns casos, o conselho de administração, diante de uma oferta voluntária de aquisição, procura outro interessado em adquirir o controle da companhia por considerar uma melhor opção para a sociedade.

Diferentemente do Brasil, nos Estados Unidos a própria companhia pode lançar uma OPA concorrente com o objetivo de frustrar uma oferta hostil. Algumas companhias brasileiras têm 
inserido cláusulas nesse sentido em seus estatutos sociais, porém a Lei das Sociedades por Ações veda a aquisição das próprias ações pela companhia, sendo tal operação permitida apenas em casos excepcionais e listados no artigo 30 da lei societária, o que não inclui a hipótese de OPA concorrente. 


\section{Controle Societário}

A Lei das Sociedades por Ações optou por expressamente definir a figura de "acionista controlador" para fins de responsabilização dos atos praticados com abuso de poder por aquele que dirige a sociedade. De acordo com o artigo 116 da lei societária brasileira:

"Art. 116. Entende-se por acionista controlador a pessoa, natural ou jurídica, ou o grupo de pessoas vinculadas por acordo de voto, ou sob controle comum, que:

a) é titular de direitos de sócio que lhe assegurem, de modo permanente, a maioria dos votos nas deliberações da assembléia-geral e o poder de eleger a maioria dos administradores da companhia; e

b) usa efetivamente seu poder para dirigir as atividades sociais e orientar o funcionamento dos órgãos da companhia.

Parágrafo único. O acionista controlador deve usar o poder com o fim de fazer a companhia realizar o seu objeto e cumprir sua função social, e tem deveres e responsabilidades para com os demais acionistas da empresa, os que nela trabalham e para com a comunidade em que atua, cujos direitos e interesses deve lealmente respeitar e atender."

O presente capítulo tem como objetivo analisar o conceito de acionista controlador previsto na Lei das Sociedades por Ações, com foco na alínea "a" do artigo 116 acima transcrito. Ademais, vamos pontuar os tipos de controle existentes e as suas funções nas ofertas públicas obrigatórias e nas ofertas públicas voluntárias.

\section{IV.1. Características Gerais}

Nas palavras de Modesto Carvalhosa ${ }^{22}$, "controlar uma companhia, portanto, é o poder autônomo de impor permanentemente

\footnotetext{
${ }^{22}$ CARVAlHOSA, Modesto. Comentários à Lei das Sociedades Anônimas. $2^{\circ}$ volume. $5^{\mathrm{a}}$ edição. São Paulo: Saraiva, 2011. p. 587.
} 
a vontade nos atos sociais e, via de consequência, de dirigir o processo empresarial, que é o seu objeto".

No Brasil, as sociedades por ações têm como órgão primário a assembleia geral, constituindo a última instância das decisões e com poderes para investir os demais órgãos. É em torno da assembleia geral que normalmente se situa o poder de dirigir as atividades sociais, já que o poder de controle está normalmente fundado na titularidade da maioria das ações com direito a voto.

No entanto, há casos em que o controle da companhia é exercido em função de dependência externa, como no suprimento de matérias-primas, no escoamento de produção e até no endividamento. Trata-se do controle chamado externo, em oposição ao controle interno, caracterizado pela atuação do titular do controle no interior da sociedade.

A Lei das Sociedades por Ações apenas previu o chamado controle interno, não havendo, portanto, previsão legal para o controle externo no Brasil, diferentemente do que ocorre em outros países. Fábio Konder Comparato e Calixto Salomão Filho enumeram quatro modalidades de controle interno existentes: (i) controle totalitário; (ii) controle majoritário; (iii) controle interno; e (iv) controle gerencial. ${ }^{23}$

\footnotetext{
${ }^{23}$ Em sua obra "The modern corporation and private property", Berle e Means identificaram cinco tipos de controle (controle com quase completa titularidade acionária, controle por meio de expediente legais, controle da maioria, controle da minoria e controle gerencial). Comparato, ao examinar detidamente a classificação proposta pelos autores americanos, reduziu as modalidades de controle interno às quatro formas identificadas neste trabalho. A esse respeito, vide COMPARATO, Fábio Konder; SALOMÃO FILHO, Calixto. O Poder de Controle na Sociedade Anônima. $4^{\text {a }}$ edição. Rio de Janeiro: Ed. Forense, 2005. p. 51-79.
} 
No controle totalitário, nenhum acionista é excluído do poder de dominação da sociedade. Isso pode ocorrer em razão de um único acionista ser o titular da totalidade das ações de emissão da companhia (i.e., em se tratando de uma subsidiária integral), de as ações de emissão da companhia serem distribuídas exclusivamente entre os membros de uma mesma família ou um mesmo, ou, ainda, em razão de um acionista deter virtualmente a totalidade das ações de emissão da companhia, com um acionista minoritário sendo detentor de uma participação ínfima no quadro acionário apenas para estabelecimento da pluralidade de sócios.

No âmbito desta modalidade de controle, não há conflito entre os interesses de acionistas, nem direito de recesso ou qualquer outro mecanismo de proteção dos interesses de acionistas minoritários, tendo em vista que não há outro interesse a ser levado em consideração além do interesse do controlador. Não é o caso, portanto, de nenhuma companhia aberta, em que necessariamente há acionistas minoritários cujos interesses devem ser preservados.

Já o controle majoritário é o que mais nos interessa nesse estudo, além do controle interno, tendo em vista que a estrutura societária da maioria das companhias brasileiras gira em torno destas modalidades de controle. Além disso, como já mencionamos neste estudo, as ofertas públicas por alienação de controle são realizadas em companhias cujo capital é concentrado, ou seja, cujo controle é detido por um acionista ou grupo de acionista, tendo em vista o requisito de transferência do controle acionário.

A principal característica do controle majoritário reside no fato de que a maioria de votos nas deliberações da assembleia geral de acionistas é detida pelo mesmo acionista (ou grupo de acionistas), o 
que significaria, na opinião de Berle e $\mathrm{Means}^{24}$, o primeiro passo na dissociação entre propriedade acionária e controle:

\begin{abstract}
"Majority control, the first step in the separation of ownership and control, involves ownership of a majority of the outstanding stock. In the case of a simple corporate structure, the ownership of a majority of the stock by a single individual or small group gives to this group virtually all the legal powers of control which would be held by a sole owner of the enterprise and in particular the power to select the board of directors. Certain powers of control, such as the power to amend the charter or to discontinue the enterprise, may require more than a simple majority vote and to that extent the majority exercises less control than a sole owner. Further, the powers of control may be to a slight extent curbed by the existence of a compact minority which is ready to question the policy or acts of the majority both directly, at stockholders' meetings and in the courts. Where all stock except that held by the majority interest is widely scattered, on the other hand, majority ownership (in the absence of a "legal device") means undiminished actual control. At the same time, the concentrating of control in the hands of a majority means that the minority have lost most of the powers of control over the enterprise of which they are part owners. For them, at least, the separation of ownership and control is well nigh complete, though for the majority the two functions are combined." 25
\end{abstract}

O controle minoritário, por sua vez, é comum nas companhias cujo capital está disperso ou pulverizado, não sendo possível identificar um acionista ou grupo de acionistas que detenha a maioria absoluta das ações com direito a voto. O controle de tal companhia é, então, exercido por um acionista ou grupo de acionistas que, sendo

\footnotetext{
${ }^{24}$ BERLE, Adolph Augustus; MEANS, Gardiner C. The Modern Corporation \& Private Property. New Brunswick: Transaction Publishers, 1991, pp. 67-68.

${ }^{25}$ Tradução livre: "Controle majoritário, o primeiro passo na separação de titularidade e controle, envolve titularidade da maioria das ações em circulação. No caso de uma estrutura societária simples, a titularidade da maioria do capital por um único indivíduo ou por um grupo pequeno dá a esse grupo virtualmente todos os poderes de controle legais que seriam detidos por um único titular da empresa, em especial o poder de eleger a diretoria. Certos poderes de controle, como o poder de alterar o estatuto social ou encerrar a empresa, podem requerer mais do que o voto da maioria simples e, nesse sentido, a maioria exerce menos poder que o único titular. Além disso, os poderes de controle podem ser, até certo nível, cerceados pela existência de uma minoria compacta que está preparada para questionar as políticas ou atos da maioria tanto diretamente, em assembleias gerais, quanto judicialmente. Enquanto todas as ações exceto as detidas pelo interesse da maioria estejam dispersas, a titularidade da maioria (na ausência de um "dispositivo legal") significa um controle de fato irrestrito. Ao mesmo tempo, a concentração do controle nas mãos de uma maioria significa que a minoria perdeu a maior parte dos poderes de controle sobre a empresa de que são parcialmente donos. Para eles, ao menos, a separação de titularidade e controle está quase completa, apesar de, para a maioria, as duas funções estarem combinadas."
} 
titular de uma participação acionária relevante, seja atuante nas assembleias gerais de acionistas e dotado de influência sobre a administração.

A GVT, companhia adquirida no caso objeto deste trabalho, era controlada por acionistas que detinham, em conjunto, aproximadamente $30 \%$ do capital social de tal sociedade. Tratava-se, portanto, de controle minoritário exercido em sociedade com capital pulverizado. Neste contexto e conforme estudamos no Capítulo III acima, a oferta pública voluntária era uma eficiente alternativa para aquisição do controle da GVT.

Quando as sociedades por ações apresentam alto nível de dispersão acionária conjugado com a ausência de uma minoria organizada, os administradores da companhia podem ter espaço para assumir o controle da companhia. Essa situação de exercício do controle empresarial "de fato" é conhecida como controle interno gerencial. É o que nos ensina Fábio Konder Comparato ao citar o caso de uma companhia americana na década de $1920^{26}$ :

"Exemplo histórico [de controle gerencial] é o da Pennsylvania Railroad Co., em dezembro de 1929, na qual os vinte maiores acionistas detinham em conjunto $2,70 \%$ do capital social, sendo que o maior acionista individual não possuía mais do que $0,34 \%$ da totalidade das ações."

Importante notar que o controle gerencial é fundado no exercício das funções diretivas da companhia e não na titularidade de participação acionária. Esse cenário, na opinião de Berle e Means, corresponderia à máxima evidência de dissociação entre controle e propriedade; em contrapartida, o controle gerencial torna a companhia mais carente de boas práticas de governança corporativa ${ }^{27}$.

\footnotetext{
${ }^{26}$ COMPARATO, Fabio Konder; SALOMÃO FILHO, Calixto. Op. cit., p. 71.

${ }^{27}$ BERLE, Adolph Augustus; MEANS, Gardiner C. Op. cit., p. 71.
} 
Depois de conceituarmos as modalidades de controle indicadas pela doutrina brasileira, passaremos agora à analise dos requisitos previstos no artigo 116 da Lei das Sociedades por Ações para a configuração do chamado acionista controlador.

De acordo com Modesto Carvalhosa ${ }^{28}$, a Lei das Sociedades por Ações estabelece três requisitos para a caracterização do controlador: (i) que ele seja titular dos direitos de sócios; (ii) que ele tenha assegurado a maioria dos votos nas deliberações da assembleia geral e o poder de eleger a maioria dos administradores; e (iii) que ele use efetivamente o seu poder na condução dos negócios sociais e, consequentemente, no funcionamento dos órgãos da companhia.

Depreende-se dos requisitos mencionados acima e conforme ensina Nelson Eizirik, a Lei das Sociedades por Ações reconhece a existência do poder de controle não em função da titularidade da maioria das ações com direito a voto, mas no efetivo exercício da direção das atividades sociais. Ainda de acordo com Eizirik: ${ }^{29}$

"O controle da sociedade anônima constitui um poder de fato, não um poder jurídico, visto que não há norma que o assegure. $\mathrm{O}$ acionista controlador não é sujeito ativo do poder de controle, mas o tem enquanto for titular de direitos de voto em número suficiente para obter a maioria nas deliberações assembleares."

De acordo com a alínea "a" do artigo 116, o acionista controlador é aquele que detém direitos de voto que lhe assegurem a maioria dos votos nas assembleias e o poder de eleger a maioria dos administradores de forma permanente. No entanto, a legislação societária não definiu os parâmetros para caracterizar a

\footnotetext{
${ }^{28}$ CARVALHOSA, Modesto. Comentários à Lei das Sociedades Anônimas. $2^{\mathrm{o}}$ volume. $5^{\mathrm{a}}$ edição. São Paulo: Saraiva, 2011. p. 574 e ss.

${ }^{29}$ EIZIRIK, Nelson. A Lei das S/A Comentada. Volume I. São Paulo: Quartier Latin, 2011. p. 665 e ss.
} 
"permanência". A maioria da doutrina, então, tem utilizado o parâmetro previsto pela revogada Resolução CMN 401/ano, que considerava como controlador o acionista titular de ações que lhe assegurassem a maioria absoluta dos votos dos acionistas presentes nas três últimas assembleias gerais.

Nesse contexto, vale ainda mencionar trecho do voto proferido pelo Diretor-Relator Pedro Oliva Marcílio de Souza no Caso CBD, o qual explicamos abaixo. Segundo ele, "vencer uma eleição ou preponderar em uma decisão, não é suficiente. É necessário que esse acionista possa, juridicamente, fazer prevalecer sua vontade sempre que desejar".

Já a alínea "b" do artigo 116 prevê a necessidade de uso efetivo do poder pelo acionista na condução das atividades sociais e na orientação do funcionamento dos órgãos da companhia. Ao tratar do conceito de acionista controlador, José Waldecy Lucena assevera:

"Do contrário, embora detentor da titularidade acionária exigida, se não se envolve com as atividades sociais nem com o funcionamento da companhia, não será ele obviamente controlador, assimilando-se, antes, a um preferencialista investidor, ou seja, o chamado acionista passivo." ${ }^{30}$

Importante reforçar o entendimento de que este requisito de "uso efetivo" é apenas necessário para fins de responsabilização do acionista controlador e definição dos seus deveres, conforme explicamos quando tratamos da alienação de controle no âmbito das ofertas públicas obrigatórias. Este assunto, no entanto, resta controverso.

\footnotetext{
${ }^{30}$ LUCENA, José Waldecy. Das Sociedades Anônimas: Comentários à Lei. Volume I. Rio de Janeiro: Renovar, 2009. p. 1074.
} 
Vale ainda mencionar neste ponto que alguns autores entendem que o uso efetivo do poder não é requisito nos casos das sociedades cujo controle é majoritário. Fábio Konder Comparato e Calixto Salomão Filho possuem esse posicionamento. Segundo eles:

\begin{abstract}
"A exigência de uso efetivo do poder "para dirigir as atividades sociais e orientar o funcionamento dos órgãos da companhia" somente se compreende, como elemento integrante da definição do controlador, em se tratando de controle minoritário. Neste, com efeito, o titular de direitos de sócios que lhe assegurariam a preponderância nas deliberações sociais, em razão da dispersão acionária, pode manter-se ausente das assembleias gerais, perdendo com isto, de fato, o comando da empresa. Já no controle de tipo majoritário, porém, o desuso ou mau uso do poder não é elemento definidor do status, pois ainda que o controlador afete desinteressar-se dos negócios sociais, não pode arredar o fato de que o poder de comando se exerce em seu nome, ou pode delegação sua, ou a que tanto equivale."’31
\end{abstract}

\title{
IV.2. Conceito de Controle para as Agências Reguladoras
}

Para referência do leitor, abaixo se encontram exemplos do conceito de alteração de controle de acordo com resoluções normativas de algumas agências reguladoras, tais como ANATEL, ANEEL, ANS e CADE. Tais agências reguladoras resolveram definir a alteração do controle das sociedades sujeitas à sua regulamentação para fins de aprovação prévia por tais agências de operações que acarretam a alteração do poder de comando das sociedades.

\section{IV.2.1. ANATEL}

De forma distinta da Lei das Sociedades por Ações, a Resolução n 101 da ANATEL, de 4 de fevereiro de 1999, apresenta

\footnotetext{
${ }^{31}$ COMPARATO, Fabio Konder; SALOMÃO FILHO, Calixto. Op. cit., p. 87.
} 
de forma expressa o conceito de controle societário, sem vincular tal fenômeno exclusivamente à detenção de participação acionária:

"Art. $1^{\circ}$ No exercício das funções de órgão regulador e de órgão competente para controle, prevenção e repressão das infrações da ordem econômica, no setor de telecomunicações, a ANATEL, com vistas à apuração de controle e de transferência de controle que sejam objeto de vedação, restrição, limites ou condicionamentos, adotará os seguintes conceitos:

I - Controladora: pessoa natural ou jurídica ou ainda o grupo de pessoas que detiver, isolada ou conjuntamente, o poder de controle sobre pessoa jurídica;

II - Controle: poder de dirigir, de forma direta ou indireta, interna ou externa, de fato ou de direito, individualmente ou por acordo, as atividades sociais ou o funcionamento da empresa.

$\S 1^{\circ}$ Sem prejuízo de outras situações fáticas ou jurídicas que se enquadrem no conceito de Controladora, para fins de evitar fraude às vedações legais e regulamentares à propriedade cruzada e à concentração econômica e de resguardar a livre concorrência e o direito dos consumidores de serviços de telecomunicações, é equiparada a Controladora a pessoa que, direta ou indiretamente:

I - participe ou indique pessoa para membro de Conselho de Administração, da Diretoria ou órgão com atribuição equivalente, de outra empresa ou de sua controladora;

II - tiver direito de veto estatutário ou contratual em qualquer matéria ou deliberação da outra;

III - possua poderes suficientes para, por qualquer mecanismo formal ou informal, impedir a verificação de quorum qualificado de instalação ou deliberação exigido, por força de disposição estatutária ou contratual, em relação às deliberações da outra, ressalvadas as hipóteses previstas em lei;

IV - detenha ações ou quotas da outra, de classe tal que assegure o direito de voto em separado a que se refere o art. 16, III, da Lei $n^{\circ}$ 6.404/76.

$\S 2^{\circ}$ Para efeito deste Regulamento, o funcionamento da empresa compreende, entre outros aspectos, o planejamento empresarial e a definição de políticas econômico-financeiras, tecnológicas, de engenharia, de mercado e de preços ou de descontos e reduções tarifárias."

Como podemos verificar a partir da análise do artigo transcrito acima, a Resolução ${ }^{\circ}$ 101/99 da ANATEL é a norma que, no ordenamento jurídico brasileiro, se aproxima de forma mais concreta 
da realidade econômica das companhias. Com efeito, o conceito de controle societário adotado pela autarquia com relação às sociedades atuantes no ramo das telecomunicações reflete o poder externo de dirigir as atividades sociais ou o funcionamento da empresa, seja ele de fato ou de direito. Além disso, a referida norma regulamentar é incisiva ao equiparar ao controlador qualquer pessoa que detenha direito de veto contratual em qualquer matéria ou deliberação de determinada companhia.

\section{IV.2.2.ANEEL}

A ANEEL aprovou no dia 17 de abril deste ano a Resolução Normativa $n^{\circ} 484$ que estabelece os procedimentos a serem adotados pelas concessionárias, permissionárias e autorizadas de serviços e instalações de energia elétrica para obtenção de anuência à transferência de controle societário. Segundo tal resolução normativa:

"Art. 2o Caracteriza o controle societário o poder de imposição de vontade aos atos da sociedade, exercido pela pessoa natural ou jurídica, ou o grupo de pessoas vinculadas por acordo de voto, ou sob controle comum, que:

a) é titular de direitos de sócio que lhe assegurem, de modo permanente, a maioria dos votos nas deliberações da sociedade e o poder de eleger a maioria dos administradores; e

b) usa efetivamente seu poder para dirigir as atividades sociais e orientar o funcionamento dos órgãos da sociedade.

Art. 3o Para os fins do disposto nesta Resolução, considera-se:

I - controle societário direto o exercido pela(s) pessoa(s) detentora(s) dos direitos de voto da delegatária, caracterizado nos termos do artigo anterior;

II - controle societário indireto o exercido por pessoa(s) no ápice da estrutura societária do grupo societário, que influencie(m) de forma efetiva e substancial a gestão e consecução do objeto social da delegatária através de outras controladas, que exercem controle societário intermediário;

III - controle societário intermediário o controle em que a(s) pessoa(s) que não detém poder de controle direto e nem indireto exerce $(\mathrm{m})$ sobre as sociedades que estão abaixo do controlador indireto e acima do controlador direto da delegatária;

IV - grupo societário o conjunto de pessoas ou entidades que em suas relações de capital estão conectadas em razão de controle societário; e 
V - o Fundo de Investimento em Participação - FIP equiparado à pessoa" jurídica.

Como se pode notar, a ANEEL resolveu utilizar os mesmos requisitos previstos na Lei das Sociedades por Ações para a caracterização de controle, ou seja: (i) preponderância nas deliberações sociais e na eleição de administradores de modo permanente; e (ii) uso efetivo do seu poder para dirigir as atividades sociais e orientar o funcionamento dos órgãos da sociedade.

\section{IV.2.3.ANS}

De acordo com o $\S 1^{\circ}$ do artigo $1^{\circ}$ da Resolução Normativa $\mathrm{n}^{\circ}$ 270, de 10 de outubro de 2011, que regula a autorização pela ANS dos atos que acarretam a transferência do controle de operadoras de planos de assistência à saúde:

" $1^{\circ}$ Considera-se alteração ou transferência de controle societário toda modificação societária que atribua a pessoa natural ou jurídica, ou a grupo de pessoas vinculadas por acordo de voto, ou sob controle comum, a condição de controlador, diretamente ou através de outras controladas, de maneira the assegurar, de modo permanente, preponderância nas deliberações sociais e o poder de eleger a maioria dos administradores, nos termos da legislação societária.

$\S 2^{\circ}$ Nos casos em que o controle é exercido por pessoa, ou grupo de pessoas, que não seja titular de ações ou quotas que asseguram a maioria absoluta dos votos do capital social, considera-se controlador a pessoa ou o grupo de pessoas vinculados por acordo de acionistas ou quotistas, ou sob controle comum, que seja o titular de ações ou quotas que lhe assegurem a maioria absoluta dos votos dos acionistas ou quotistas presentes nas três últimas Assembléias Gerais da operadora.

Como podemos perceber, a norma da ANS repete o requisito da alínea "a" do artigo 116 da Lei das Sociedades por Ações, qual seja, de preponderância nas deliberações sociais e no poder de eleger a maioria dos administradores, de modo permanente. Desta forma, 
para fins de aprovação prévia da ANS, não há necessidade de uso efetivo deste poder pelo alienante ou pelo adquirente.

\section{IV.2.4 CADE}

De acordo com a Lei de Defesa da Concorrência, o CADE pode considerar acionistas minoritários como controladores, dependendo dos direitos decorrentes de suas participações em determinada companhia. Dessa forma, essencial verificar, sob a ótica concorrencial, o conceito de poder de controle e os limites de influência que a participação minoritária confere ao acionista.

Para o CADE, controle "é o poder de dirigir, de forma direta ou indireta, interna ou externa, de fato ou de direito, individualmente ou por acordo, as atividades sociais e/ou o funcionamento da empresa", estando diretamente associada ao poder de tomar decisões mercadológicas. Dessa forma, a análise antitruste pressupõe não apenas o exame das formas societárias, mas da realidade econômica em si, no que se convenciona chamar de influência relevante ${ }^{32}$ : "a partir da união dos centros decisórios em áreas específicas e estratégicas $^{33}$, seja possível presumir um comportamento cooperativo

\footnotetext{
${ }^{32}$ COELHO, Fábio Ulhôa. Reforma do Estado e Direito Concorrencial. A importância do poder de controle para o Direito Concorrencial da economia globalizada. In: SUNDFELD, Carlos Ari (coord.). Direito Administrativo Econômico. São Paulo: Malheiros, 2002. p.197: “...o conceito de controlador não precisa ser idêntico nestes quatro ramos do direito (societário, fiscal, bancário e concorrencial), uma vez que deve atender aos objetivos específicos de cada uma destas disciplinas. Qual o objetivo do Direito Concorrencial? Garantia da concorrência. (...) no Direito Alemão, precursor da teorização neste campo, o poder de controle era conceituado como o de "influência dominante" (beherrschender einflu $\beta$ ). O Direito de Concorrência Germânico, desde há alguns anos, afastou o conceito de influência dominante para adotar o conceito de influência significativa do ponto de vista concorrencial (Wettbeswerblich erheblicher Einflu $\beta)$.”

${ }^{33}$ Quatro áreas são consideradas fundamentais pela doutrina para permitir esse controle do planejamento empresarial: pesquisa e desenvolvimento, investimento, produção e vendas
} 
entre as empresas, o qual não pressupõe a titularidade da maioria das ações votantes ${ }^{34}$.

De acordo com a jurisprudência do CADE, consolidada na Súmula CADE $\mathrm{n}^{\mathrm{o}}$ 2, de 27 de agosto de 2007, um acionista minoritário exerce influência relevante quando demonstrado: (i) seu interesse em intervir na atuação da empresa no mercado (como, por exemplo, a coincidência dos objetos sociais entre acionista e sociedade); (ii) a possibilidade ou (iii) a efetividade do exercício da influência nas decisões empresariais (alguma prerrogativa ou privilégio que lhe confira um poder de decisão) $)^{35}$.

Em termos práticos, o minoritário será considerado como controlador pelo CADE, sempre que, isolada ou cumulativamente, detiver os seguintes direitos sobre a empresa na qual detém participação: (i) indicar quaisquer administradores (independentemente do número de administradores indicados e do percentual que representam do total de administradores da Companhia em questão); (ii) determinar política comercial; ou (iii) vetar qualquer matéria social que afete as atividades diárias da empresa.

Ao ser equiparado a controlador, o minoritário passa a ser considerado pelo CADE, juntamente com o acionista majoritário,

\footnotetext{
${ }^{34}$ Ato de Concentração ${ }^{0}$ 08012.010293/2004-48, em que eram Requerentes Ideiasnet S.A e Flynet S. A.

${ }^{35}$ FILHO, Calixto Salomão. Direito Concorrencial - as estruturas. $2^{\mathrm{a}}$ edição. São Paulo: Malheiros, 2002, p.257: "Não basta o poder de determinar a prática de um ato isolado (como ocorre no direito societário, onde um ato isolado pode causar prejuízo patrimonial à empresa, seus acionistas minoritários, credores e empregados). (...) Por este motivo, não basta para caracterizar a influência dominante (no sentido concorrencial) a possibilidade ou mesmo a probabilidade de influenciar um ato isolado. É preciso que o poder tenha bases estruturais estáveis, de forma a fazer pressupor que perdurará no tempo."

“(...) o controle interno, quando minoritário, deve ser acompanhado de algum qualificador que garanta ou ao menos permita presumir a existência de influência duradoura."
} 
como um participante efetivo do mercado em que a empresa controlada atua. 


\section{AnÁlise JuRisprudencial Sobre Alienação de CONTROLE}

Após a análise do s conceitos doutrinários e dos dispositivos legais aplicáveis às ofertas públicas previstas no direito societário brasileiro e ao conceito de controle, especialmente para fins de alienação ou aquisição de controle, iremos estudar neste capítulo alguns leading cases da CVM, precedentes que serviram para consolidar o entendimento desta autarquia com relação às hipóteses de configuração de alienação de controle e a obrigatoriedade ou não de se realizar oferta pública.

Como a oferta hostil ainda é um instituto de utilização recente no direito brasileiro e a oferta lançada pela Vivendi para aquisição do controle da GVT foi por alienação do controle (e não aquisição originária), na maioria dos casos ora estudados a discussão se deu em torno da aplicabilidade ou não do artigo 254-A da Lei das Sociedades por Ações. A única exceção é o caso Arcelor-Mittal, no qual se discutiu a previsão de nova hipótese de oferta pública no estatuto social da Arcelor Brasil (conforme definido abaixo).

Vale ressaltar neste primeiro momento o entendimento já consolidado da CVM com relação a aplicabilidade do artigo 116 da Lei das Sociedades por Ações para fins de configuração de controle e obrigatoriedade de oferta publica, nos termos do artigo 254-A da referida lei. Como podemos extrair dos votos dos diretores da CVM, não é necessário o uso efetivo do controle da uma companhia para fins de oferta pública, mas apenas o poder de eleger a maioria dos administradores e dirigir a atividade social. Assim, no âmbito do artigo 254-A, aplica-se apenas o conceito explicitado pela alínea "a" do artigo 116 mencionado acima. 
Feitas essas primeiras considerações, os seguintes casos julgados pela CVM serão detalhadamente analisados: (i) o caso CBD; (ii) o caso Arcelor-Mittal; (iii) o caso TIM; e (iv) o recente caso da Usiminas. Além desses, vamos também mencionar outras decisões importantes da CVM em casos similares envolvendo oferta pública de aquisição por alienação de controle societário.

\section{v.1. O Caso CBD}

A decisão da CVM e o voto do Diretor-Relator Pedro Oliva Marcilio de Souza no caso envolvendo a alienação do controle da Companhia Brasileira de Distribuição (“ $\underline{\mathrm{CBD}}$ ”) foram emblemáticos no direito societário brasileiro e têm sido utilizados como parâmetro e referência por diversos doutrinadores e consultores, incluindo outros diretores da CVM na análise de casos similares.

Em 3 de maio de 2005, Abílio dos Santos Diniz (incluindo outros membros de sua família) ("Abílio") e Casino Guichard Perrachon S.A. ("Casino”) celebraram um acordo de associação, segundo o qual, ao final da implementação das operações ali previstas, Abílio e Casino seriam detentores cada um de 50\% das ações ordinárias e com direito a voto de uma sociedade holding pura, a qual seria a controladora direta da CBD detendo 61,19\% das ações de tal sociedade.

Desta forma, com o acordo de associação acima descrito e a celebração de um acordo de acionistas entre Abílio e Casino, tais acionistas exerceriam indiretamente o controle compartilhado da CBD. Importante ainda notar que Casino detinha diretamente $26,12 \%$ 
da ações ordinárias e com direito a voto da $\mathrm{CBD}$, além de ações preferenciais tanto da CBD quanto da sociedade holding.

Antes da celebração do acordo de associação, o capital social da CBD era controlado direta e indiretamente por Abílio, e o Casino detinha apenas 30,53\% das ações com direito a voto da CBD. $\mathrm{Na}$ reorganização feita em 2005, então, não houve a entrada de um terceiro estranho à sociedade, mas os acionistas controladores permaneceram indiretamente os mesmos, alterando apenas suas respectivas participações acionárias.

O acordo de associação ainda previu a opção de compra pelo Casino de uma ação ordinária emitida pela sociedade holding e detida pelo Abílio pelo preço de $\mathrm{R} \$ 1,00$ a ser exercida em oito anos a contar da celebração do acordo de associação, o que, segundo a CBD, não acarretaria necessariamente na alteração do seu controle indireto tendo em vista se tratar de uma opção de compra que pode ou não ser exercida em oito anos.

No entanto, a Procuradoria Federal Especializada da CVM ("PFE") e a Área Técnica da CVM entenderam que as operações previstas no acordo de associação resultavam na alienação do controle da CBD para fins do artigo 254-A da Lei das Sociedades por Ações, sendo necessária a realização da oferta pública. A PFE, por meio do seu parecer, entendeu que:

“(iv) embora a opção só possa ser exercida 8 anos após as Operações, o seu preço de exercício é ínfimo ( $\mathrm{R} \$ 1,00)$, assim "para adquirir um direito dessa natureza e magnitude [assunção do controle da Recorrente], [o Comprador] já teria pago, [aos Vendedores], o seu respectivo preço, quando da celebração do 'Acordo de Associação' e do 'Acordo de Acionistas [da Recorrente]', consolidando-se, na esfera jurídica [do Comprador], a aptidão para exercer, de forma concentrada, o poder de mando sobre [a Recorrente], fato que, de per se, caracteriza a alienação do controle dessa companhia; e 
(v) "[i]nterpretando-se ampliativamente o art. 254-A, é possível depreender-se, com segurança, que o legislador pretendeu abranger situações como a presente, que em tudo se assemelha à alienação de bônus de subscrição ou de outros valores mobiliários conversíveis em ações com direito a voto."

A CBD recorreu da decisão da Área Técnica da CVM argumentando, dentre outros pontos, que para configuração da alienação de controle para fins de oferta pública seria necessário considerar a definição de acionista controlador prevista no artigo 116 da Lei das Sociedades por Ações, incluindo o uso efetivo do poder de controlador para dirigir as atividades sociais, conforme a alínea "b" do referido dispositivo legal.

O colegiado da CVM manifestou-se no âmbito do Processo Administrativo CVM n ${ }^{\circ}$ RJ 2005/4069, confirmando o entendimento da sua Área Técnica e da PFE que houve alienação do controle da CBD, devendo ser aplicado o disposto no artigo 254-A da Lei das Sociedades por Ações.

Em seu voto na qualidade de Diretor-Relator, Pedro Oliva Marcilio de Souza analisou a aplicabilidade do artigo 116 na configuração de alienação de controle do artigo 254-A da Lei das Sociedades por Ações. Segundo ele, tais dispositivos tratam de situações diferentes, já que o artigo 116 está preocupado em definir o acionista controlador para efeitos de responsabilidade e o artigo 254A "pretende conferir uma "compensação" à quebra da estabilidade do quadro acionário", permitindo a alienação das ações dos acionistas minoritários por um preço mínimo determinado pela lei.

Além disso, o Diretor-Relator ressalta que o artigo 254-A não faz qualquer menção ao artigo 116 e que seu $\S 1^{\circ}$ "apenas vinculou a alienação de controle à transferência de valores mobiliários, indicado 
que está preocupado apenas com o requisito do artigo 116, alínea "a". Entende então Pedro Oliva Marcilio de Souza que a alínea "b" do artigo 116, ou seja, o uso efetivo do poder de controlador, não deve ser considerado para efeitos de oferta pública de alienação de controle.

Pedro Oliva Marcilio de Souza analisou também os efeitos dos acordos de voto para fins do artigo 254-A: o que seria importante é que com a transferência, o alienante fique com menos de $50 \%$ das ações com direito a voto e o adquirente com, no mínimo, 50\% mais uma ação com direito a voto. Desta forma, mesmo se houver acordos de voto que assegurem ao alienante o exercício de fato do poder de controle, seria necessária a oferta pública para alienação de controle. Ao contrário, "a transferência de direitos políticos e econômicos para terceiros sem transferência de valores mobiliários pode dar causa a oferta pública, em virtude da previsão de alienação direta ou indireta" (grifo nosso).

Já com relação à possibilidade de se considerar que a alienação de controle da CBD já ocorreu, mesmo que o Casino tenha uma opção de compra a ser exercida em oito anos que vai lhe garantir este controle, o Diretor-Relator concorda com o entendimento da Área Técnica e da PFE que o Casino já está considerando no preço de aquisição o exercício desta opção de compra e, consequentemente, a compra do controle da $\mathrm{CBD}$, devendo a oferta pública ser realizada desde logo. No Capítulo VI deste trabalho, que trataremos da opção de compra dentro do conceito de alienação de controle, voltaremos a mencionar o voto do Pedro Oliva Marcílio de Souza neste caso. 


\section{V.2. O Caso Arcelor-Mittal}

O Processo Administrativo CVM RJ 2006/6209 teve como objetivo analisar o recurso interposto por Mittal Steel Company N.V. ("Mittal"), uma companhia aberta holandesa controlada por integrantes da família Mittal, contra a decisão conjunta da SRE e da SEP que entenderam pela obrigatoriedade de se realizar oferta pública de aquisição aos acionistas minoritários da Arcelor Brasil S.A. ("Arcelor Brasil") por força do disposto no artigo 10 do estatuto social de tal companhia brasileira, tendo em vista a aquisição do controle pela Mittal da Arcelor S.A. (“Arcelor”), uma companhia aberta luxemburguesa com controle disperso.

Em um primeiro momento, faz-se necessário narrar os fatos que levaram à mencionada aquisição do controle da Arcelor pela Mittal. Em janeiro de 2006, a Mittal anunciou sua intenção de realizar uma oferta pública hostil, ou seja, não solicitada, aos acionistas da Arcelor. No entanto, o conselho de administração da Arcelor manifestou-se contra tal oferta. Em maio de 2006, a Mittal fez a primeira revisão da oferta, melhorando os seus termos e condições sob o ponto de vista dos acionistas da Arcelor. O conselho de administração da Arcelor, porém, continuou a se opor à oferta.

No dia 25 de junho de 2006, Arcelor e Mittal divulgaram em conjunto a celebração de um memorando de entendimentos, pelo qual as partes acertaram os termos da oferta para aquisição do controle da Arcelor a ser lançada pela Mittal. A operação pretendida seria uma "transação entre iguais" (merger of equals) e as partes empregariam seus melhores esforços para que houvesse, no futuro, a fusão entre a Arcelor e a Mittal. 
A operação mencionada acima foi divulgada ao mercado brasileiro por meio de fato relevante da Arcelor Brasil, publicado em 5 de julho de 2006. Segundo o disposto em tal fato relevante, a Arcelor e a Mittal entenderam que "as transações previstas no MOU não constituirão aquisição de controle da Arcelor Brasil” para fins do artigo 254-A da Lei das Sociedades por Ações e dos artigos 8 a 10 do estatuto social da Arcelor Brasil, mas teve como objetivo realizar uma "fusão entre iguais".

Os acionistas minoritários da Arcelor Brasil protocolaram reclamação perante a CVM defendendo a necessidade de realização de oferta pública de aquisição com fulcro no artigo 10 do estatuto social de tal companhia ${ }^{36}$. A SEP e a SRE manifestaram-se no sentido de que a Mittal, como adquirente do controle indireto da Arcelor Brasil, teria o dever legal de cumprir a obrigação prevista no estatuto social daquela companhia, ou seja, de realizar oferta pública para os minoritários da Arcelor Brasil.

Tal entendimento teve como base o memorando preparado pela PFE que entendeu que a oferta pública decorreu do estatuto social da Arcelor Brasil e não do artigo 254-A da lei societária brasileira. Ademais, a obrigação estatutária teria incidido no momento que a Mittal adquiriu mais de 50\% das ações da Arcelor, não importando a intenção das partes em se fundirem no futuro, se certas condições forem cumpridas e dependendo dos melhores esforços das companhias.

\footnotetext{
${ }^{36}$ Estabelecia o artigo 10 do estatuto social da Arcelor: "A oferta pública de aquisição de ações a que se refere o Artigo $8^{\circ}$ será também exigida caso uma pessoa, que não uma Pessoa Relacionada, adquira o poder de controle da Companhia por meio de aquisição de ações de emissão do acionista controlador final da Companhia. Neste caso, a sociedade objeto da aquisição do poder de controle ficará obrigada a declarar à Bolsa de Valores de São Paulo ("Bovespa") a mudança em seu controle acionário e a sociedade adquirente deste ficará obrigada a declarar à Bovespa o valor atribuído à Companhia nessa alienação." (grifo nosso)
} 
Contra a decisão da SRE e da SEP, a Mittal apresentou recurso perante o colegiado da CVM, defendendo o posicionamento de que não houve aquisição do controle da Arcelor, com base em diversos argumentos, dentre os quais os seguintes: (i) não competência da CVM para impor obrigações que não estivessem relacionadas com comandos previstos em lei ou na regulamentação; (ii) os acionistas da Arcelor aceitantes da oferta receberam ações da Mittal, permanecendo como acionistas indiretos da Arcelor; e (iii) o artigo 10 do estatuto social da Arcelor Brasil não prevê uma nova hipótese de realização de oferta pública, mas apenas reforça que deverá ser feita oferta pública se ocorrer a aquisição do controlador final da companhia, não importando em que localidade tal controlador esteja.

O Diretor-Relator Wladimir Castelo Branco Castro proferiu seu voto, o qual foi seguido pelos demais diretores, mantendo o entendimento da SRE e da SEP e a obrigatoriedade de realização de oferta pública pela Mittal aos minoritários da Arcelor Brasil em razão da aquisição do poder de controle por meio da aquisição de ações do acionista controlador final da Arcelor Brasil, conforme disposto no artigo 10 do estatuto social desta companhia.

Refutando o argumento da Mittal de que a CVM não teria competência para impor obrigações previstas estatutariamente, o diretor defendeu que a não observância de cláusula do estatuto social pelos acionistas controladores causaria danos aos acionistas minoritários, sendo dever legal da CVM defendê-los e, consequentemente, impor obrigações estatutárias. Tal competência decorreria tanto da Lei das Sociedades por Ações quanto da Lei do Mercado de Capitais, que instituiu esta autarquia. 
Adicionalmente, com relação à interpretação mais adequada ao artigo 10 do estatuto social da Arcelor Brasil, Wladimir Castelo Branco Castro entende que tal artigo previu uma oferta pública inexistente no direito societário brasileiro, para o caso de uma aquisição originária de controle da sua controladora final, conferindo aos acionistas minoritários brasileiros o direito de se retirar pelo mesmo preço oferecido aos acionistas da Arcelor. Tal interpretação faz sentido na estrutura societária da Arcelor Brasil e da Arcelor, tendo em vista que o controle desta é pulverizado no mercado.

Como o estatuto social da Arcelor Brasil fala em aquisição do "poder de controle", e não acionista controlador, o Diretor-Relator não achou necessário analisar o artigo 116 da Lei das Sociedades por Ações e considerou poder de controle como o "poder de decidir em uma instância a atividade empresarial". Segundo ele, tal conceito refere-se à dominação vertical, ou seja, de cima para baixo.

Diante do disposto acima, o poder de controle da Arcelor Brasil será transferido com a aquisição do poder de controle da Arcelor, o qual, segundo o diretor, deve ser definido de acordo com os parâmetros estabelecidos pela lei societária de Luxemburgo, qual seja a aquisição de $33,3 \%$ dos direitos de voto da Arcelor (critério de controle presumido).

Com base nos fatos e argumentos levantados acima, o colegiado da CVM entendeu pela obrigatoriedade de oferta pública para os acionistas minoritários da Arcelor Brasil por força de dispositivo estatutário prevendo a oferta pública em caso de aquisição originária do controle, hipótese esta que não se encontra prevista na lei societária brasileira atual. 


\section{V.3. O Caso TIM}

No âmbito do Processo Administrativo CVM n ${ }^{0}$ RJ 2009/1956, a CVM, representada pelos diretores Eliseu Martins (como DiretorRelator), Maria Helena dos Santos Fernandes de Santana (como Diretoria Presidente), Otavio Yazbek, Marcos Barbosa Pinto e Eli Loria, analisou o recurso contra a decisão da SRE, nos autos do Processo Administrativo CVM n ${ }^{\circ}$ RJ 2007/14344, que concluiu pela obrigatoriedade de oferta pública para a alienação indireta do controle da TIM Participações S.A. (“TIM”).

A operação ora em análise teve por objeto a alienação da totalidade das ações de emissão da Olimpia S.p.A. ("Olimpia”), sociedade italiana que detinha $17,99 \%$ das ações da Telecom Italia S.p.A ("Telecom Italia"), a qual, por sua vez, detinha indiretamente $81,24 \%$ das ações emitidas pela TIM.

Em razão da alienação das ações da Olimpia realizada na Itália, os acionistas minoritários da TIM recorreram à CVM alegando a necessidade de oferta pública de aquisição de ações, nos termos do artigo 254-A da Lei das Sociedades por Ações, tendo em vista ser a Olímpia controladora de fato da TIM e, portanto, ter ocorrido alienação indireta do controle desta companhia.

Conforme mencionado acima, em um primeiro momento a SRE decidiu pela obrigatoriedade de oferta pública como requisito para alienação do controle da TIM. No entanto, em julho de 2009, a CVM reformou tal decisão, com votos favoráveis dos diretores Maria Helena dos Santos Fernandes de Santana, Otavio Yazbec e Eli Loria. 
Este caso ora estudado teve como peculiaridade a discussão sobre a aplicabilidade da lei brasileira ou da lei italiana para definir se houve ou não alienação do controle e se era obrigatória a oferta pública no Brasil. A Diretora Presidente Maria Helena dos Santos Fernandes de Santana entendeu ser aplicável a lei italiana ao caso e, com base nesta, foi afastada a necessidade de oferta pública.

Os demais diretores aplicaram a legislação brasileira sobre controle e oferta pública, mais especificamente os artigos 116 e 254A, $\S 1^{\circ}$ da Lei das Sociedades por Ações. Otavio Yazbek, na mesma linha que os demais diretores no tocante à aplicação da alínea "a" do artigo 116 da Lei das Sociedades por Ações para a definição de controle para efeitos da obrigatoriedade de oferta pública, entendeu que o controle exercido pela Olimpia na Telecom Italia não era estável e permanente, tendo em vista que em uma assembleia da Telecom Italia realizada em 2007, a Olimpia obteve apenas 49,94\% dos votos válidos, não atingindo $50 \%$ de tais votos. Desta forma, Otavio Yazbek vota pelo deferimento do recurso e pela desnecessidade de realização da oferta pública de aquisição de ações, afirmando que:

\footnotetext{
"Parece-me que não há como reconhecer, de forma inequívoca, que a alienação da totalidade das ações da Olimpia para a Telco asseguraria a esta a detenção de direitos hábeis a lhe garantir, de modo permanente, a posição de controladora indireta da Telecom Italia e, consequentemente, da TIM Participações"
}

No mesmo sentido do voto proferido por Otavio Yazbek, Eli Loria entende que a oferta pública de aquisição de ações da TIM não é obrigatória no caso concreto, tendo em vista que "o bloco de ações alienado não assegura direitos de sócios" de formar a garantir o poder de eleição da maioria dos membros do conselho de administração de forma permanente. 
Eliseu Martins, por sua vez, votou pelo indeferimento do recurso e, consequentemente, pela obrigatoriedade de oferta pública no caso em tela. O Diretor-Relator compartilha do mesmo entendimento que o ilustre Fábio Konder Comparato, pelo qual o artigo 116 da Lei das Sociedades por Ações engloba sim o controle minoritário. Além disso, segundo este diretor, o conceito de permanência trazido no mencionado artigo não exige solidez absoluta, mas apenas uma certa continuidade. É indubitável, afirma ele, que a Olimpia tinha o controle da Telecom Italia e, indiretamente, da TIM Participações.

Em seu voto, Eliseu Martins ainda menciona outros aspectos que ajudam a corroborar a tese que houve transferência de controle, dentre os quais destacam-se: (i) o pagamento de prêmio na aquisição das ações da Olimpia; (ii) a anuência da ANATEL para a transferência do controle da TIM Participações, impondo restrições ao exercício deste poder de controle; e (iii) a análise da operação pelas autoridade de defesa da concorrência brasileira. Adicionalmente, o diretor afirma que "as circunstâncias apontadas como indicadoras da inexistência de controle não parecem ser suficientes".

Pela análise do caso aqui exposto sobre a alienação do controle indireto da TIM foi possível verificar que ainda há diversos aspectos controvertidos sobre controle no direito brasileiro, não havendo uma posição clara na doutrina e na jurisprudência sobre esta matéria e, especialmente, acerca da obrigatoriedade de oferta pública para alienação do controle definido como minoritário. 


\section{V.4. O Caso Usiminas}

A Usinas Siderúrgicas de Minas Gerais S.A. ("Usiminas") divulgou por meio de fato relevante publicado em 28 de novembro de 2011 a celebração de determinados contratos de compra e venda de ações que, dentre outras consequências, ensejaram na saída de um dos membros do bloco de controle de tal companhia e a consequente entrada de um terceiro a este bloco de controle. Com a implementação das operações contempladas nos contratos de compra e venda, a estrutura do bloco de controle da Usiminas passou a ser a seguinte:

(i) O Grupo Nippon, que já pertencia ao bloco de controle da Usiminas com 27,76\% das ações ordinárias de tal companhia, passou a deter $29,45 \%$ das ações ordinárias da Usiminas;

(ii) $\mathrm{O}$ Grupo $\mathrm{T} / \mathrm{T}$, que não possuía qualquer participação acionária na Usiminas, adquiriu 27,66\% das ações ordinárias de tal companhia; e

(iii) A Caixa dos Empregados da Usiminas ("CEU”), que alienou parte das ações ordinárias que detinha na Usiminas, permaneceu no bloco de controle de tal companhia detendo 6,75\% das ações ordinárias da Usiminas.

Faz-se necessário ressaltar que o Grupo V/C, o qual antes da implementação desta reorganização detinha $25,97 \%$ das ações ordinárias da Usiminas, vendeu toda a sua participação em tal sociedade para o Grupo $\mathrm{T} / \mathrm{T}$, não possuindo mais qualquer participação acionária na Usiminas. Adicionalmente, foi celebrado 
um novo acordo de acionistas entre os atuais membros do bloco de controle da Usiminas, o qual era, em sua essência, similar ao acordo de acionistas existente.

Desta forma, as operações implementadas na Usiminas tiveram como principal objetivo a entrada de um terceiro estranho à sociedade no seu bloco de controle com a conseqüente saída de um dos grupos pertencentes a tal bloco de controle. Além disso, o Grupo Nippon reforçou a sua participação majoritária no bloco de controle da Usiminas e a CEU reduziu a sua participação no capital da mesma companhia, permanecendo, no entanto, no bloco de controle da Usiminas.

A SRE, pretendendo analisar detalhadamente estas operações de modo a verificar a necessidade de oferta pública de aquisição pela alienação do controle da Usiminas, instaurou um processo na Área Técnica e, após a devida análise, decidiu pelo seu arquivamento, entendendo que não houve alienação do controle da Usiminas.

De acordo com o parecer elaborado por Ricardo Maia da Silva, o Gerente de Registros 1 ("Parecer"), a Usiminas alegou em sua defesa que não houve alienação do seu controle acionário, já que não houve a "substituição de um antigo controlador por um novo" e que o Grupo T/T não assumiu o poder de conduzir as atividades sociais da Usiminas.

Ricardo Maia da Silva, fazendo referência ao voto do DiretorRelator Pedro Oliva Marcilio de Souza no âmbito do caso da CBD, filia-se ao entendimento que, para configuração da alienação de controle para efeitos do artigo 254-A da Lei das Sociedades por Ações, é necessário que (i) haja mudança na titularidade do poder de 
controle, com a presença de um novo controlador; (ii) a transferência do controle seja onerosa; e (iii) tenha ocorrido a transferência de ações do antigo controlador.

Desta forma, o gerente de registros manifesta-se no sentido que o Grupo V/C, que alienou todas as suas ações ao Grupo T/T, não detinha uma participação majoritária dentro do bloco de controle. Adicionalmente, o Grupo T/T, mesmo com a compra complementar de 1,69\% das ações ordinárias detidas pelo CEU, não ultrapassou a participação detida pelo Grupo Nippon, que inclusive reforçou a sua participação majoritária por meio das operações realizadas. Assim, não houve a substituição do antigo controlador por um novo, já que nem o Grupo V/C assumia uma posição de controle nem o Grupo T/T passou a assumir tal posição.

Ricardo Maia da Silva menciona ainda que o Grupo T/T não terá o direito de eleger a maioria dos membros da administração da Usiminas com o novo acordo de acionistas celebrado, o que afasta a tese de que um novo membro do bloco de controle assumiu efetivamente a posição de acionista controlador da Usiminas.

Em 30 de março de 2011, a CVM proferiu a sua decisão entendendo pela não necessidade de realização de oferta pública de aquisição de ações no presente caso.

\section{V.5. Outros Casos}

No Processo CVM RJ 2001/10329, a CVM analisou a alienação de $28 \%$ do capital votante da Aracruz Celulose S.A. (“Aracruz") para Votorantim Celulose e Papel S.A. ("Votorantim”), 
participação esta que compunha o bloco de controle da Aracruz. Importante esclarecer que a Votorantim não era acionista da Aracruz na época da operação. A decisão proferida pela CVM foi no sentido de não obrigatoriedade de se realizar uma oferta pública de aquisição, já que não houve alienação do controle, mas de parte das ações que constituem o bloco de controle. Trata-se de um caso semelhante ao da Usiminas, estudado acima.

Já no caso da aquisição de ações detidas por acionista integrante do bloco de controle da COPESUL - Companhia Petroquímica do Sul (“COPESUL”) pela Braskem S.A. ("Braskem”), que já era integrante do bloco de controle desta sociedade, mas não o exercia diretamente, a CVM também se manifestou no sentido de não incidência de oferta pública de aquisição. Segundo o diretor Eli Loria, para que haja alienação de controle é necessária a entrada de um terceiro estranho à sociedade, o que não era o caso, pois a Braskem era membro do bloco de controle da COPESUL. Já o diretor Marcelo Trindade afirmou que o controle de uma sociedade só pode ser alienado por todas as pessoas vinculadas por um acordo de voto e não apenas por um membro de tal grupo que detenha menos que a maioria das ações com voto. (Processo CVM RJ 2007/7230).

Finalmente, vale mencionar o Processo CVM RJ 2009/0471 envolvendo a alienação do controle da Companhia Energética do Ceará (“COELCE”). A Acciona S.A. e a Enel Energy Europe S.R.L adquiriram 46,05\% do capital votante da Endesa S.A. ("Endesa"), a qual era controladora da COELCE. Tal porcentagem adquirida fazia parte do bloco de controle da Endesa. Neste caso, a CVM entendeu que não era necessário realizar uma oferta pública de aquisição, tendo em vista que não havia um bloco de controle formal, mas apenas acordos de acionistas tácitos. Desta forma, não poderia se falar em 
transferência direta do controle da Endesa e indiretamente da COPESUL.

Os quatro casos detalhadamente estudados e os outros três casos mencionados neste capítulo são considerados emblemáticos e têm sido utilizados como referência na análise e decisão de diversos casos similares. Além disso, tais casos refletem o entendimento pacificado da CVM com relação a diversos pontos sobre alienação de controle de uma companhia, seja tal alienação direta ou indireta, e sobre a obrigatoriedade de oferta pública de aquisição. 


\section{As Opções de Compra para Caracterização do Controle}

De acordo com os fatos narrados no Capítulo II acima, a Vivendi celebrou contratos de opção de compra de ações de emissão da GVT com terceiros, por meio dos quais a companhia francesa passou a deter o direito de adquirir 25.134.327 ações da GVT, representando 19,6\% do capital social de tal companhia.

Em contrapartida à aquisição das opções de compra, a GVT pagou aos terceiros um prêmio de opção ao preço de $\mathrm{R} \$ 1,00$. O preço de exercício por ação era de $\mathrm{R} \$ 55,00$, sendo certo que, na hipótese de a oferta pública de aquisição de ações que seria realizada pela Vivendi ser concluída e o preço pago no âmbito de tal oferta for superior a $\mathrm{R} \$ 56,00$, a Vivendi teria que pagar a diferença aos terceiros alienantes. Vale ainda ressaltar que tais opções se tornaram incondicionadas em 13 de novembro de 2009, data em que a Vivendi anunciou ao mercado que detinha o controle da GVT.

Como o controle da GVT estava sob disputa pública, com o leilão da Telefônica para a aquisição voluntária marcado para meados de novembro, quando da divulgação de que tal controle da GVT tinha sido transferido para a Vivendi, muito se questionou acerca das opções de compra que a Vivendi tinha adquirido: se elas eram firmes, se elas garantiam efetivamente o controle da GVT, se o alienante das opções tinha direito ao seu exercício imediato, se todas as opções de compra poderiam ser liquidadas fisicamente, conferindo direito de voto e não apenas os direitos econômicos relativos a tais ações, dentre outros questionamentos nessa linha. 
Não se pretende neste trabalho adentrar no mérito das opções de compra adquiridas pela Vivendi, já que não houve acesso público tal documentação e, com isso, torna-se impossível fazer uma análise objetiva e completa sobre este assunto. Importante ainda notar que neste contexto foi celebrado um Termo de Compromisso entre a Vivendi e a CVM, não tendo o colegiado da autarquia reguladora dos mercados de capitais analisado e decidido sobre o mérito desta questão.

Nesse sentido, a análise a seguir será restrita ao instituto das opções de compra em geral e se a aquisição de tais opções pode caracterizar a aquisição do controle de uma companhia, principalmente para fins da obrigatoriedade de realização de uma oferta pública de aquisição por alienação de controle. Dispõe o $\S 1^{\circ}$ do artigo 254-A da Lei das Sociedades por Ações:

"§1 $1^{\circ}$ Entende-se como alienação de controle a transferência, de forma direta ou indireta, de ações integrantes do bloco de controle, de ações vinculadas a acordos de acionistas e de valores mobiliários conversíveis em ações com direito a voto, cessão de direitos de subscrição de ações e de outros títulos ou direitos relativos a valores mobiliários conversíveis em ações que venham a resultar na alienação de controle acionário da sociedade."

Pela redação do $\S 1^{\circ}$ acima, verifica-se que a legislação societária previu como alienação do controle de uma sociedade a transferência de direitos relativos a valores mobiliários conversíveis em ações. As opções de compra configuram direitos sobre as próprias ações, garantindo ao titular de tais opções a titularidade das ações de determinada companhia.

Como se pode observar, se a transferência de direitos relativos a valores mobiliários conversíveis em ações obriga a realização de oferta pública de aquisição, a transferência das chamadas opções de 
compra também devem obrigar o lançamento de uma OPA, se tais opções forem firmes e garantirem ao seu titular o controle da companhia.

No entanto, alguns autores entendem que a obrigação de realizar oferta pública para os casos de direitos de subscrição, transferência de valores mobiliários conversíveis em ações ou de direitos sobre tais valores mobiliários apenas se concretizam no momento do exercício dos direitos previstos, ou seja, na subscrição das novas ações e na conversão dos valores mobiliários em ações. Nesse sentido, leciona Modesto Carvalhosa:

\footnotetext{
"Por outro lado, tratando-se de valores mobiliários conversíveis em ações, não é a sua aquisição que caracteriza a alienação do controle, mas a sua efetiva conversão em ações. Como referido, a lei societária não cogita de controle potencial, mas de controle efetivo, ou seja, de uma relação fática que se materializa mediante o poder de dirigir os negócios sociais e de eleger a maioria dos administradores (art. 116 e 243, $\$ 2^{\circ}$ ). Assim, se o adquirente de debêntures conversíveis em ações, em montante tal que lhe permitiria assumir o controle da companhia, nunca converte tais debêntures em ações, não se caracteriza a alienação do controle, pois tal debenturista em tal situação não chegará jamais a exercer os direitos de acionista que lhe assegurariam o poder de controle (art. 116)., ${ }^{37}$
}

De fato, a mera aquisição de valores mobiliários conversíveis em ações não pode, por si só, disparar a obrigatoriedade de realização de OPA se, quando da conversão de tais valores mobiliários, o adquirente passar a deter ações que lhe garantam o controle da companhia. No entanto, devem ser analisados outros aspectos de tal transferência e da possibilidade de conversão imediata dos valores mobiliárias ou a existência de condicionantes.

No caso das opções de compra, a análise da obrigatoriedade ou não de realização de oferta pública deve ser feita de acordo com as

37 CARVAlHOSA, Modesto. Comentários à Lei das Sociedades Anônimas. $4^{\mathrm{o}}$ volume. Tomo II. $4^{\mathrm{a}}$ edição. São Paulo: Saraiva, 2011. p. 221. 
peculiaridades do caso, levando em consideração a possibilidade de se exercer imediatamente ou apenas no futuro os direitos previstos em tais opções. Nesse sentido, o Pronunciamento Técnico CPC 36 (R2) editado pelo Comitê de Pronunciamentos Contábeis estabeleceu o conceito de controle para fins de consolidação das demonstrações financeiras da controlada na controladora. Transcrevemos tais regras abaixo:

“13. Presume-se que exista controle quando a controladora possui, direta ou indiretamente por meio de suas controladas, mais da metade do poder de voto da entidade, a menos que, em circunstâncias excepcionais, possa ficar claramente demonstrado que tal relação de propriedade não constitui controle. O controle também pode existir no caso de a controladora possuir metade ou menos da metade do poder de voto da entidade, quando houver:

(a) poder sobre mais da metade dos direitos de voto por meio de acordo com outros investidores;

(b) poder para governar as políticas financeiras e operacionais da entidade conforme especificado em estatuto ou acordo;

(c) poder para nomear ou destituir a maioria dos membros da diretoria ou do conselho de administração, ou de órgão de administração equivalente, quando o controle da entidade é exercido por esses órgãos;

(d) poder para mobilizar a maioria dos votos nas reuniões da diretoria ou do conselho de administração, ou de órgão de administração equivalente, quando o controle da entidade é exercido por essa diretoria ou conselho.

14. A entidade pode possuir valores mobiliários conversíveis em ações com direito a voto, tais como opções de compra de ações não padronizadas (warrants), opcões de compra de acões, bônus de subscrição de ações, debêntures conversíveis e outros direitos ou instrumentos patrimoniais ou de dívida conversíveis em ações com poder de voto, os quais, se exercidos ou convertidos, conferem à entidade poder de voto adicional ou reduzem o poder de voto de outras partes sobre as políticas financeiras e operacionais de outra entidade (ou seja, constituemse em potenciais direitos de voto). A existência e o efeito dos potenciais direitos de voto, prontamente exercíveis ou conversíveis, incluindo os potenciais direitos de voto mantidos por outras entidades, devem ser considerados quando da avaliacão do poder de uma entidade de governar as políticas financeiras e operacionais de outra entidade. Os potenciais direitos de voto que não forem prontamente exercíveis ou conversíveis no momento dessa avaliação não devem ser considerados. Esse é o caso, por exemplo, quando não puderem ser exercidos ou convertidos até uma data futura ou até a ocorrência de um evento futuro.

15. Ao avaliar se os potenciais direitos de voto contribuem para o controle, a entidade deve examinar todos os fatos e circunstâncias (incluindo os termos de exercício dos potenciais direitos de voto e qualquer outro acordo contratual, considerados individualmente ou em conjunto) que possam afetar os potenciais direitos de voto, exceto a 
intenção da administração e a capacidade financeira para exercê-los ou convertê-los." (grifos nossos)

O item 14 do normativo acima transcrito nos chama atenção por mencionar expressamente as opções de compra de ações, tal como no caso da Vivendi. Interpretando tal normativo, podemos dizer que uma companhia que possui opções de compra imediatamente exercíveis que lhe garantam o poder de comando de determinada sociedade pode ser considerada como a sua controladora.

Importante ainda mencionar nesse contexto o voto do diretor Pedro Oliva Marcílio de Souza no âmbito do Caso CBD explicado no capítulo anterior. Naquele caso, o Casino detinha uma opção de compra de uma ação da CBD pelo preço de $\mathrm{R} \$ 1,00$, opção esta que só poderia ser exercida depois de oitos anos da data do contrato. Esta ação objeto da opção de compra garantiria ao Casino a maioria dos votos nas deliberações sociais da CBD.

Neste caso, o Diretor-Relator Pedro Oliva Marcílio de Souza acompanhou o entendimento da Área Técnica pela obrigatoriedade de se realizar uma oferta pública por alienação do controle da CBD de imediato, tendo em vista que já teria sido pago o preço para o exercício de tal opção pelo Casino. Ademais, o adiamento da oferta pública levaria à impossibilidade de se calcular o preço a ser pago aos acionistas minoritários. Segundo a Área Técnica da CVM:

"(iii) a análise dos contratos das Operações indicam que, com o exercício da opção que permite a aquisição de uma ação do Controlador Direto, o Comprador assumirá o seu controle, assumindo a posição de AD que, por sua vez, assumirá o status antes atribuído ao Comprador;

(iv) embora a opção só possa ser exercida 8 anos após as Operações, o seu preço de exercício é ínfimo ( $\mathrm{R} \$ 1,00)$, assim "para adquirir um direito dessa natureza e magnitude [assunção do controle da Recorrente], [o Comprador] já teria pago, [aos Vendedores], o seu respectivo preço, quando da celebração do 'Acordo de Associação' e do 'Acordo de 
Acionistas [da Recorrente]', consolidando-se, na esfera jurídica [do Comprador], a aptidão para exercer, de forma concentrada, o poder de mando sobre [a Recorrente], fato que, de per se, caracteriza a alienação do controle dessa companhia"; e

(v) "[i]nterpretando-se ampliativamente o art. 254-A, é possível depreender-se, com segurança, que o legislador pretendeu abranger situações como a presente, que em tudo se assemelha à alienação de bônus de subscrição ou de outros valores mobiliários conversíveis em ações com direito a voto"."

Percebemos então que a CVM obrigou a realização de uma oferta pública em um caso que a opção de compra não era imediatamente exercível, mas que o seu preço já havia sido pago pelo adquirente e, portanto, a possibilidade de não exercício da opção depois de decorridos os oito anos impostos no contrato era improvável. Este caso consubstancia o entendimento de que as opções de compra de ações devem ser analisadas caso a caso para fins de alienação de controle e realização de oferta pública de aquisição.

Adicionalmente, José Alexandre Tavares Guerreiro enumera os requisitos que devem ser observados na configuração de alienação de controle, quais sejam: (i) transferência onerosa, direta ou indireta; (ii) de títulos que garantam; (iii) o controle da companhia; (iv) para pessoas ou grupo de pessoas estranho ao grupo de controle $^{38}$. Analisando esses requisitos objetivamente, podemos concluir que a transferência de uma opção de compra que garanta ao seu adquirente o controle da companhia pode ser considerada uma alienação de controle e, consequentemente, disparar a realização da oferta pública prevista no artigo 254-A da Lei das Sociedades por Ações.

\footnotetext{
${ }^{38}$ GUERREIRO, José Alexandre Tavares. Sociedade Anônima. Reorganização Societária. Alienação de Ações. Alienação de controle direta e indireta: inocorrência. Inaplicabilidade do art. 254-A da Lei das Sociedades por Ações. Revista de Direito Bancário e do Mercado de Capitais. São Paulo: Editora Afiliada, ano 12, n. 45. p. 211. jul./set. 2009
} 
Diante dos argumentos expostos acima, o entendimento de que uma opção de compra não tem o condão de garantir o controle de uma companhia até o momento de seu exercício não deve prosperar. $\mathrm{Na}$ verdade, esta tese vai de encontro ao objetivo do artigo 254-A de proteção aos acionistas minoritários de uma companhia aberta. Se um terceiro estranho à sociedade passa a deter opções de compra da maioria das ações de determinada sociedade que podem ser exercidas a qualquer tempo e sem qualquer condição, tal terceiro teria poder sobre a sociedade desde já, nos termos do artigo 254-A da Lei das Sociedades por Ações.

Conforme divulgado no dia 13 de novembro de 2009, a Vivendi havia adquirido ações representativas de $37,9 \%$ do capital social da GVT, além de ter celebrado contratos de opção de compra de ações incondicionadas que representariam adicionais 19,6\% do capital social da GVT. A Vivendi fez ainda outras aquisições no mercado depois de referida data, de forma a consolidar o seu controle, além de exercer todas as opções que detinha antes do final do ano de 2009.

Diante destes fatos, percebe-se que a intenção da Vivendi era de fato a aquisição do controle da GVT e o argumento de Modesto Carvalhosa de que o adquirente do direito sobre os valores mobiliários pode querer não exercer seus direitos não deve ser utilizado neste caso, em que a intenção da Vivendi era claramente exercer os direitos que detinha o mais rápido que pudesse.

Ademais, os contratos de opção de compra celebrados pela Vivendi com terceiros eram incondicionados e exercíveis a qualquer tempo. As regras e requisitos previstos no Pronunciamento CPC 36 
(R2) que exigem que as opções devam ser imediatamente exercíveis para fins de controle foram, então observadas.

Por fim, vale ressaltar que a discussão sobre as opções de compra adquiridas pela Vivendi, sem entrar no mérito de tais opções, originou-se, especialmente, por estar em curso, naquela época, uma oferta pública hostil lançada pela Telefônica para a aquisição do controle da GVT. Desta forma, como o controle da GVT estava sob disputa, era muito provável que se discutissem como foi a aquisição de tal controle pela Vivendi, a conduta da companhia francesa e a firmeza dos opções de compra celebrados que garantiram o controle da GVT. Se a Vivendi não tivesse se comprometido a realizar a oferta pública prevista no artigo 254-A da Lei das Sociedades por Ações por entender que ainda não havia o controle, os minoritários muito provavelmente iriam reclamar perante a CVM e a discussão teria mudado de foco. 


\section{CONCLUSÕES}

O presente estudo permitiu uma análise detalhada dos diversos institutos de direito societário aplicáveis no caso de alienação do controle de uma companhia aberta. Foram apontados pontos controvertidos envolvidos em tais temas e como a doutrina e a jurisprudência têm se manifestado acerca das discussões.

Como se pode perceber, a realização das chamadas OPAs obrigatórias é muito mais frequente no direito brasileiro do que as OPAs voluntárias, ou hostis. Isto ocorre em razão da estrutura do capital da maioria das companhias brasileiras, que são controladas por acionistas majoritários (controle majoritário). As OPAs hostis, no entanto, são realizadas quando há alta dispersão acionária na companhia. Desta forma, mesmo que o instituto da OPA hostil tenha sido previsto na Lei das Sociedades por Ações em sua redação original de 1976, a utilização deste instituto no Brasil ainda é muito recente.

Há uma discussão atualmente acerca da adoção de um critério objetivo, ou um número mágico, para fins de disparar a obrigatoriedade da OPA por alienação de controle. A adoção de tal critério traria mais segurança jurídica para o Brasil, evitando discussões sobre a obrigatoriedade de se realizar uma oferta pública no caso concreto e, assim, evitando que muitos casos sejam analisados pela CVM.

O critério objetivo, no entanto, é aconselhado em países cuja estrutura do capital das companhias é diferente da estrutura do Brasil, como nos países membros da União Européia, ou seja, em países em que a maioria das companhias tem controle pulverizado e base 
acionária dispersa. Desta forma, o ideal seria esperar uma evolução do mercado brasileiro, com uma pulverização do controle das companhias, de forma a se adotar um número mágico que de fato terá efetividade para o direito societário brasileiro.

Adicionalmente, outro ponto que tem ensejado controvérsia no âmbito das OPAs obrigatórias diz respeito ao conceito de alienação de controle para fins do artigo 254-A da Lei das Sociedades por Ações. Diante de todos os argumentos expostos neste trabalho, o entendimento mais coerente tende a ser pela aplicabilidade parcial do artigo 116 de referida lei societária. Nesse sentido, é necessário apenas o cumprimento da alínea "a" de referido artigo 116, não se aplicando a alínea "b" (uso efetivo do poder) no conceito de alienação do controle para fins de OPA obrigatória.

As opções de compra, como analisado neste trabalho, podem ser consideradas para fins de caracterização de alienação de controle e, consequentemente, para disparar a obrigatoriedade de oferta pública. Para tanto, deve ser analisado no caso concreto se as opções de compra adquiridas pelo potencial novo controlador são exercíveis imediatamente ou cujo exercício é inevitável ou já foi pago por tal adquirente. De qualquer forma, é indispensável a análise das especificidades do caso.

Como se pode perceber, o direito societário no Brasil está em amplo desenvolvimento e evolução e novas discussões sobre a Lei das Sociedades por Ações, elaborada em 1976, têm surgido em recentes casos concretos. Deve ser considerado, porém, na análise dos casos e na adoção de novas regras de direito societário, que a estrutura das companhias brasileiras ainda é muito diferente da estrutura das companhias européias e/ou americanas e, portanto, não 
podemos apenas transpor as regras lá previstas para a nossa legislação. 


\section{BibliografiA}

BERLE, Adolph Augustus; MEANS, Gardiner C. The Modern Corporation \& Private Property. New Brunswick: Transaction Publishers, 1991.

CARVAlHOSA, Modesto. Comentários à Lei das Sociedades Anônimas. $2^{\circ}$ volume. $5^{a}$ edição. São Paulo: Saraiva, 2011. 1081 p.

CARVAlHOSA, Modesto. Comentários à Lei das Sociedades Anônimas. $4^{\mathrm{o}}$ volume. Tomo II. $4^{\mathrm{a}}$ edição. São Paulo: Saraiva, 2011. $1081 \mathrm{p}$.

CARVAlHOSA, Modesto. Oferta Pública de Aquisição de Ações. Rio de Janeiro: IBMEC, 1979. 608 p.

COELHO, Fábio Ulhôa. Reforma do Estado e Direito Concorrencial. A importância do poder de controle para o Direito Concorrencial da economia globalizada. In: SUNDFELD, Carlos Ari (coord.). Direito Administrativo Econômico. São Paulo: Malheiros, 2002.

COMPARATO, Fabio Konder; SALOMÃO FILHO, Calixto. $O$ Poder de Controle na Sociedade Anônima. $4^{\mathrm{a}}$ edição. Rio de Janeiro: Ed. Forense, 2005. 597 p.

COX, James D.; HILLMAN, Robert W.; LANGEVOORT, Donald C. Securities Regulation: Cases and Material. $5^{\mathrm{a}}$ edição. Nova York: Aspen Publishers, 2006. 1187 p. 
EIZIRIK, Nelson. A Lei das S/A Comentada. Volume I. São Paulo: Quartier Latin, 2011. 735 p.

EIZIRIK, Nelson. A Lei das S/A Comentada. Volume III. São Paulo: Quartier Latin, 2011. 639 p.

EIZIRIK, Nelson. Aquisição de Controle Minoritário. Inexigibilidade de Oferta Pública. In: CASTRO, Rodrigo R. Monteiro de; AZEVEDO, Luís André N. de Moura Azevedo. Poder de Controle e Outros Temas de Direito Societário e Mercado de Capitais. São Paulo: Quartier Latin, 2010. p. 177190.

FILHO, Calixto Salomão. Direito Concorrencial - as estruturas. $2^{a}$ edição. São Paulo: Malheiros, 2002.

GARNIER, Bryan A. Black's Law Dictionary. 9a edição. Saint Paul: West, 2009.

GUERREIRO, José Alexandre Tavares. Alienação de controle de companhia aberta: o papel das instituições financeiras. Revista de Direito Mercantil, Industrial, Econômico e Financeiro. São Paulo: Malheiros, n. 30. p.115-119. 1978.

GUERREIRO, José Alexandre Tavares. Sociedade Anônima. Reorganização Societária. Alienação de Ações. Alienação de controle direta e indireta: inocorrência. Inaplicabilidade do art. 254-A da Lei das Sociedades por Ações. Revista de Direito Bancário e do Mercado de Capitais. São Paulo: Editora Afiliada, ano 12, n. 45. p. 207-223. jul./set. 2009 
LUCENA, José Waldecy. Das Sociedades Anônimas: Comentários à Lei. Volume I. Rio de Janeiro: Renovar, 2009. $1232 \mathrm{p}$.

NASCIMENTO, João Pedro Barroso do. Medidas Defensivas à Tomada de Controle de Companhias. São Paulo: Quatier Latin, 2011. $285 p$.

NETO, Alfredo Sérgio Lazzareschi. Lei das Sociedades por Ações Anotada. $3^{\text {a }}$ edição. São Paulo: Saraiva, 2010

Oferta Pública de aquisição de controle: artigo 257 e seguintes da Lei 6.404/76. Estudos da Superintendência Jurídica da CVM, citação p. 33, publicado em agosto de 1979.

OIOLI, Erik Frederico. Obrigatoriedade do Tag Along na Aquisição de Controle Diluído. In: ADAMEK, Marcelo Vieira von (coord.). Temas de Direito Societário e Empresarial Contemporâneos. São Paulo: Malheiros, 2011. p. 316-326.

OIOLI, Erik Frederico. Oferta Pública de Aquisição do Controle de Companhias Abertas. São Paulo: Quartier Latin, 2010. 246 p.

PARENTE, Norma. Principais Inovações Introduzidas pela Lei $\mathrm{m}^{\circ}$ 10.303, de 31 de outubro de 2001, à Lei das Sociedades por Ações. In: LOBO, Jorge (coord.). Reforma da Lei das Sociedades Anônimas: inovações e questões controvertidas da Lei $n^{\circ} 10.303$, de 31.10.2011. $1^{\mathrm{a}}$ edição. Rio de Janeiro: Forense, 2002. 564 p.

PRADO, Roberta Nioac. Oferta Pública de Ações Obrigatória nas S.A. - Tag Along. São Paulo: Quartier Latin, 2005. 366 p. 
RIBAS, Gustavo Santamaria Carvalhal. Das Aquisições Hostis na Prática Norte-Americana e a Perspectiva Brasileira. Revista de Direito Mercantil, Industrial, Econômico e Financeiro. São Paulo: Malheiros, n. 141. p.121-129. jan./mar. 2006. 